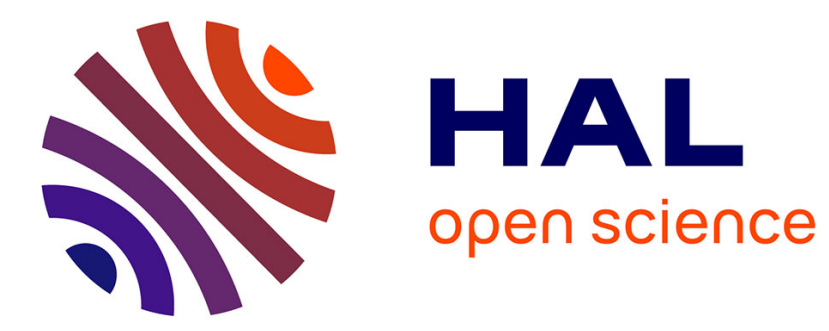

\title{
Tectonic record and gold mineralization in the central part of the Neoproterozoic Keraf suture, Gabgaba district, NE Sudan
}

Julien Perret, Julien Feneyrol, Aurélien Eglinger, Anne-Sylvie André-Mayer, Célestine Berthier, Aomar Ennaciri, Rémi Bosc

\section{To cite this version:}

Julien Perret, Julien Feneyrol, Aurélien Eglinger, Anne-Sylvie André-Mayer, Célestine Berthier, et al.. Tectonic record and gold mineralization in the central part of the Neoproterozoic Keraf suture, Gabgaba district, NE Sudan. Journal of African Earth Sciences, 2021, 181, pp.104248. 10.1016/j.jafrearsci.2021.104248 . hal-03226974

\section{HAL Id: hal-03226974 \\ https://hal.science/hal-03226974}

Submitted on 16 May 2021

HAL is a multi-disciplinary open access archive for the deposit and dissemination of scientific research documents, whether they are published or not. The documents may come from teaching and research institutions in France or abroad, or from public or private research centers.
L'archive ouverte pluridisciplinaire HAL, est destinée au dépôt et à la diffusion de documents scientifiques de niveau recherche, publiés ou non, émanant des établissements d'enseignement et de recherche français ou étrangers, des laboratoires publics ou privés. 


\section{Tectonic record and gold mineralization in the central part of the Neoproterozoic Keraf suture, Gabgaba district, NE Sudan}

Julien Perret ${ }^{1,2,}$, Julien Feneyrol ${ }^{1}$, Aurélien Eglinger ${ }^{2}$, Anne-Sylvie André-Mayer ${ }^{2}$, Célestine Berthier ${ }^{2}$, Aomar Ennaciri³ ${ }^{3}$ Rémi Bosc ${ }^{1}$

Accepted for publication in Journal of African Earth Sciences in May 2021.

\footnotetext{
${ }^{1}$ Arethuse Geology EURL, BP 80017, Latitude Arbois, 1060 rue René Descartes, 13290 Les Milles, France

${ }^{2}$ GeoRessources, Université de Lorraine, CNRS, 54000 Nancy, France

${ }^{3}$ Managem, BP5199, Twin Center, Tour A, Boulevard Zerktouni, Casablanca, Maroc
} 


\begin{abstract}
The central Keraf suture recorded complex lithospheric-scale deformation associated with the formation of the Neoproterozoic Arabian-Nubian shield and hosts the WG03, Central Zone and UTM gold deposits, Gabgaba district, northeastern Sudan. This study aims at (i) unravelling the tectonic history recorded by the central Keraf suture and (ii) interpreting the spatial and genetic relationships between structural setting and gold mineralization. To this end, we coupled field petrographic observations and structural measurements made along a $50 \mathrm{~km}$-long geological cross-section through the Gabgaba district with macroscopic and microscopic description of mineralized structures.
\end{abstract}

The structural setting of the central Keraf suture is dominated by progressive deformation, from ductile $\mathrm{D}_{1 \mathrm{a}}$ Keraf thrusting to ductile-brittle $\mathrm{D}_{1 \mathrm{~b}}$ sinistral shearing in a prolonged northwest-orientated convergence regime. A first mineralization event, leading to a minor gold endowment, relates to magmatic accretion pre-dating $\mathrm{D}_{\text {1a }}$ Keraf suturing. The second gold episode is characterized by ore veining as a response to progressive late collisional $\mathrm{D}_{1 \mathrm{~b}}$ Keraf strike-slip shearing and may be classified as orogenic gold. Most of the gold budget of the Gabgaba district formed at this stage.

In summary, the central Keraf suture exemplifies that the Arabian-Nubian shield contains significant polyphase gold mineralization along lithospheric-scale structures. These structures may record a complex tectonic evolution from magmatic accretion to collision, with a strong structural control on gold endowment.

\title{
Keywords
}

Arabian-Nubian shield; Keraf suture; Gabgaba district; thrust and strike-slip tectonics; polyphase mineralization; orogenic gold. 


\section{Introduction}

Archean to Phanerozoic orogenic gold deposits are systematically associated with crustal to lithospheric-scale structures along accretionary- and collision-type convergent margins (e.g., Kerrich and Wyman, 1990; Goldfarb et al., 2001, 2005; Groves et al., 2003, 2018, 2019; Weinberg et al., 2004; Bierlein et al., 2006; Eglinger et al., 2017). Lithospheric-scale transcurrent shear zones may develop at the boundary between lithotectonic blocks or terranes and play a critical role as fluid and magma pathways (e.g., Kerrich and Wyman, 1990; Sawkins, 1990; Weinberg et al., 2004, 2005; Blewett et al., 2010; Mole et al., 2019). Although these transcurrent shear zones mostly result from the syn- to late convergent stage, some record a much more complex polyphase deformation history starting earlier in the orogenic cycle with the formation of suture zones (e.g., Daigneault et al., 2002; Weinberg et al., 2004; Feybesse et al., 2006). These complex, transcurrent, lithospheric-scale structures are known to host orogenic gold deposits in world-class gold provinces, such as the Boulder-Lefroy fault system in the Archean Yilgarn craton (e.g., Weinberg et al., 2005; Mueller et al., 2020; Mueller, 2020), the Cadillac-Larder Lake fault zone in the Archean Abitibi subprovince (e.g., Rabeau et al., 2013; Simard et al., 2013; Bedeaux et al., 2017) or the Markoye shear zone in the Paleoproterozoic West African craton (e.g., Fontaine et al., 2017; Goldfarb et al., 2017). Several gold events may then occur from the magmatic arc accretion to the late orogenic periods (e.g., Simard et al., 2013; Augustin et al., 2017; Eglinger et al., 2017, 2020; Le Mignot et al., 2017; Thébaud et al., 2020; Masurel et al., 2021). These gold-mineralized shear zones therefore have the potential to provide important relationships between tectonic processes and gold endowment through time.

The Arabian-Nubian shield (ANS; Fig. 1a, b) constitutes the main Neoproterozoic gold province worldwide (Johnson et al., 2017). ANS deposits are mostly classified as orogenic gold occurrences preferentially hosted by major shear zones (e.g., Elsamani et al., 2001; Botros, 2002, 2004; Helmy et al., 2004; El Kazzaz, 2012; Osman, 2014; Helmy 
and Zoheir, 2015; Khalil et al., 2016; Fawzy, 2017; Zoheir et al., 2019a, 2019b, 2019c), including the Keraf shear zone (KSZ) (Johnson et al., 2017). The KSZ is mapped in northeastern Sudan and southeastern Egypt, and overprints the $\sim 500 \mathrm{~km}-\mathrm{long}, \sim 70 \mathrm{~km}-$ wide, north-striking ophiolite-decorated Keraf suture (KS) which is rooted deep into the lithosphere (Almond and Ahmed, 1987; Abdelrahman, 1993; Abdelsalam et al., 1995; Abdelsalam and Stern, 1996a; Ahmed Suliman, 2000). The KS is divided in the northern, central and southern sections with distinct structural settings, despite it remains a poorly studied area with uncertain shape and boundaries (Fig. 1c). Second-order structures are known to host gold occurrences and deposits in the central KS, forming the Gabgaba gold district explored and exploited since 2009 by Manub, a subsidiary of the Moroccan mining group Managem Ltd. (Block 15 exploration license in Fig. 1c; Managem, 2011). Yet, the temporal and spatial relationships between the Gabgaba gold district deposits, i.e., WG03, Central Zone and UTM -indicated and measured resources up to 1.659 Mozt Au, 438 kozt Au and 308 kozt Au in May 2013, respectively (Managem, 2014)- and the wider structural framework are scarcely documented (e.g., Gaboury et al., 2020):

(i) Central Zone and UTM deposits are located along a second-order structure, known as the "West Corridor" (Figs. 2, 3; Gaboury et al., 2020) but the interpretation of this structure as the western boundary of the central KS remains under debate (Fig. 2; Ahmed Suliman, 2000; Bailo et al., 2003; Abdelsalam et al., 1998; Gaboury et al., 2020).

(ii) The WG03 deposit is located along another lower-order shear zone west of the "West Corridor" (Fig. 2), it remains thus unclear if the deposit is located within the KS and if WG03 gold endowment relates in any way to KS tectonics.

Much work therefore remains to be done to understand the gold endowment history related to the central KS tectonics and the Gabgaba district is well-suited to do so. Our study serves two purposes: (i) collecting field observations and structural measurements along the central section of the KS (Figs. 1c, 2, 3) to propose a revised tectonic history, 
unifying previous models from the literature (e.g., Abdelsalam et al., 1995, 1998; Ahmed Suliman, 2000); and (ii) linking the textural and structural characteristics of the known Gabgaba deposits with the wider tectonic framework, to interpret the spatial and genetic relationships between structural setting and gold mineralization. In order to address these two points, we realized a $50 \mathrm{~km}$-long geological cross-section through the Gabgaba gold district and conducted a petrological-structural study of the WG03, Central Zone and UTM gold deposits.

\section{Geological setting}

The ANS is the northernmost part of the East African-Antarctic orogen (EAAO; Fig. 1a, b; Kröner, 1993; Stern, 1994; Kusky et al., 2003; Li et al., 2008; Seton et al., 2012; Fritz et al., 2013; Domeier and Torsvik, 2014; Merdith et al., 2017; Grenholm, 2019). Its formation resulted from the amalgamation and collision between terranes, formed by juvenile magmatic arc and ophiolite assemblages which are remnants of the subduction and obduction processes that completely consumed the Mozambique ocean in the northern EAAO (Fig. 1a; e.g., Burke and Sengör, 1986; Johnson et al., 2011; Fritz et al., 2013 and references therein). It led to the formation of suture zones that are linear belt of intense deformation along which terranes join together and sometimes superimposed by crustal-scale shear zones (Chetty, 2017). The Keraf suture and shear zone is an example of such a composite orogenic belt (KS-KSZ; Fig. 1b).

The extent of the KS is limited to Egypt and Sudan as it represents the northern part of the Keraf-Kabus-Sekerr-Kinyiki suture (Fig. 1a) that stretches to Kenya southwards (Fig. 1a; Vearncombe, 1983; Burke and Sengör, 1986; Frisch and Pohl, 1986; Berhe, 1990; Abdelsalam and Dawoud, 1991; Ries et al., 1992; Mosley, 1993; Abdelsalam et al., 1998; Fritz et al., 2013). Keraf suturing consisted in arc-continent collision between Neoproterozoic juvenile magmatic arcs, and the Saharan meta-craton with consumption 
of the Mozambique ocean lithosphere (Vail, 1983, 1985; Almond and Ahmed, 1987; Abdelsalam and Dawoud, 1991; Stern, 1994; Abdelsalam et al., 1995, 1998; Abdelsalam and Stern, 1996b; Abdelrahman et al., 2017).

The former presence of the Mozambique ocean in place of the current KS is underlined by the Keraf Pre-Tectonic Assemblage (KPTA; Fig. 1c). The KPTA gathers all the rocks exposed only in the KS zone and that are affected by Keraf thrusting and strike-slipe shearing processes (Ahmed Suliman, 2000). It comprises pre-Neoproterozoic high- to medium-grade gneisses (Meinhold, 1979; Vail, 1979; Dawoud, 1980; Abdelrahman, 1993) and rock remnants related to different geodynamical settings such as magmatic arc and back-arc basin (Keraf ophiolitic mélange, volcanosedimentary sequences; e.g., Schandelmeier et al., 1994; Stern, 1994; Abdelsalam et al., 1995; Abdelrahman et al., 2017) and passive continental margin (carbonate-rich and siliciclastic meta-sediments; e.g., Stern et al., 1993). Following the Mozambique ocean expansion, the formation of the KS-KSZ recorded its closure and subsequent convergence:

(i) Initial convergence and ocean closure occurred along a north-trending magmatic arc system that was active at $c a$. 800-750 Ma east to the Saharan meta-craton (Abdelsalam et al., 1998; Bailo et al., 2003). At the same time, west-trending aulacogenlike oceanic reentrants started to close along magmatic arcs as well, such as the one marked by the Atmur-Delgo suture, located west of the northern KS (Fig. 1c; Denkler et al., 1993, 1994; Harms et al., 1994; Schandelmeier et al., 1994; Stern et al., 1994).

(ii) Then, an oblique convergence resulted into arc-continent collision and the final closure of the oceanic reentrants and the Mozambique oceanic basin between the ANSrelated terranes and the Saharan meta-craton, leading to Atmur-Delgo and Keraf suturing between ca. 750-640 Ma (Abdelsalam et al., 1998).

(iii) Finally, oblique convergence was translated into sinistral shearing along the KS which led to its superimposition by the KSZ at ca. 640-580 Ma (Abdelsalam et al., 1998). 
The late to post-collisional lateral displacement occurred between $c a$. 630-590 Ma and is mostly recognized along the southern part of the KSZ (Evuk et al., 2014).

(iv) The orogenic activity ended along the KS-KSZ at 565 Ma (Bailo et al., 2003) and a post-orogenic gravitational collapse locally reactivated structures at $\sim 550 \mathrm{Ma}$ (Stern, 1994; Abdelsalam et al., 1995, 2003; Abdelsalam and Stern, 1996a, 1996b; Ahmed Suliman, 2000).

In the westernmost ANS, six deformation phases have been interpreted from satellite imagery by Abdelsalam et al. (1995). The first two $\left(\mathrm{D}_{1 / 2 \mathrm{ADS}}\right)$ relate to AtmurDelgo suturing and their field expression is limited to the northwestern KS (Fig. 1c; Schandelmeier et al., 1994; Abdelsalam et al., 1995, 1998, 2003; Perret et al., 2020). They are not considered further as not identified in our study area. Field data more or less robustly confirmed the existence of the four last $\mathrm{D}_{1-\mathrm{AS}}$ to $\mathrm{D}_{4-\mathrm{AS}}$ deformation events, that are attributed to the formation of KS-KSZ (Fig. 1c; Ahmed Suliman, 2000). Details about the related structures and previous tectonic interpretations are provided in Table 1. However, one can doubt that up to six deformation phases can be robustly resolved at first by remote sensing in such a complexly deformed area. This is the reason why we decided not to match the $\mathrm{D}_{1-\mathrm{AS}}$ to $\mathrm{D}_{4-\mathrm{AS}}$ deformation history and rather propose our own structural interpretation below. 

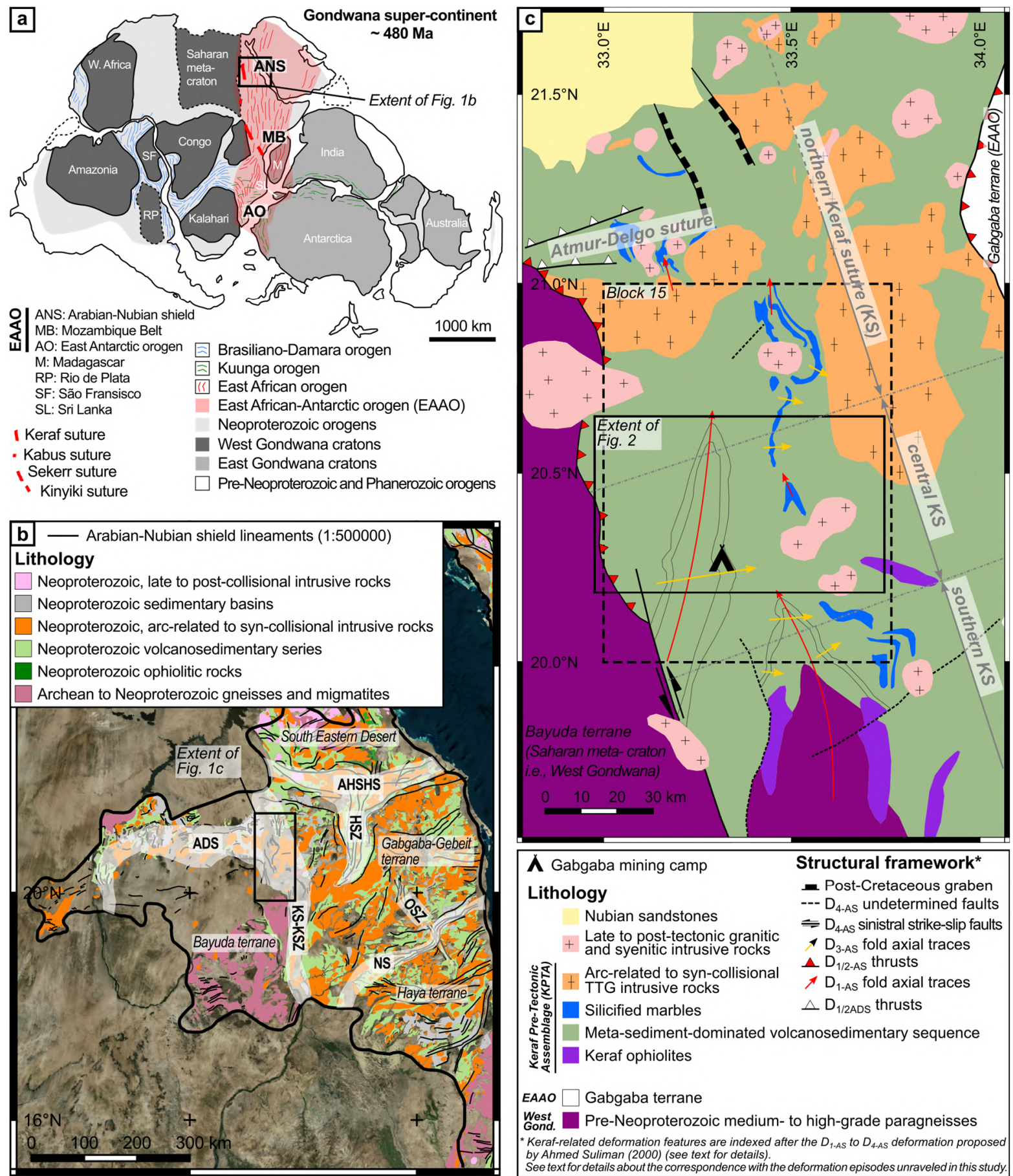

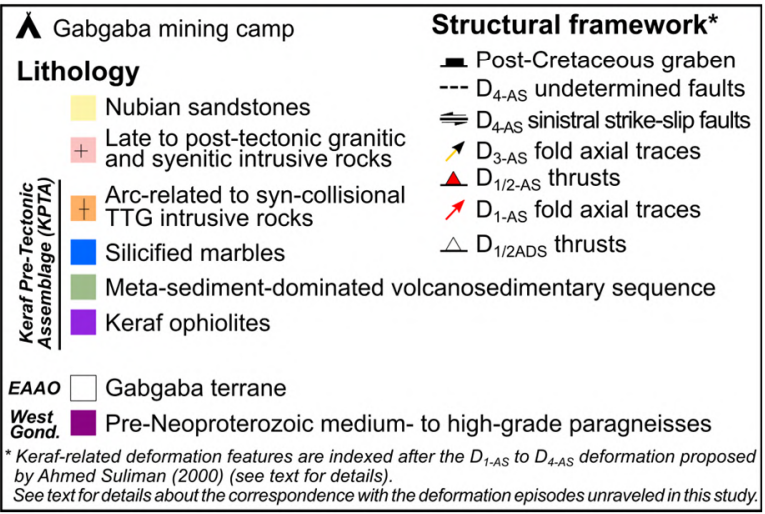

Figure 1: The Keraf suture in the framework of the East African-Antarctic orogeny (EAAO). a Gondwana supercontinent reconstruction, modified after Gray et al. (2008). The location of the Keraf-Kabus-Sekerr-Kinyiki suture along the EAAO comes from Fritz et al. (2013). b Geological map of the Nubian part of the Arabian-Nubian shield (ANS).Lithological units are drawn from Egypt, Sudan and Eritrea national geological maps (Egyptian Geological Survey and Mining Authority, 1981; Geological Research Authority of the Sudan, 1988; Tadesse et al., 2000) after legend homogenization. The main suture and shear zones as well as terrane names are indicated after Johnson et al. (2011). Abbreviations are ADS = Atmur-Delgo suture; KS-KSZ = Keraf suture-shear zone; AHSHS = Allaqi-Heiani Sol Hamed suture; HSZ = Hamisana shear zone; NS = Nakasib suture; OSZ = Oko shear zone. Background is Google Satellite imagery from which lineaments have been drawn at 1:500000 scale. The extent of Figure 1c is indicated. Geographic coordinates are reported as WGS 84. c Geological map of the central Keraf suture (KS), from Ahmed Suliman (2000) and Bailo et al. (2003). The northern, central and southern KS limits are provided. "KPTA" stands for the Keraf Pre-Tectonic Assemblage described by Ahmed Suliman (2000) gathering all lithologies within the KS. The Block 15 exploration license hosts the Gabgaba gold district which this study focuses on. The extent of Figure 2 is indicated. Geographic coordinates are reported as WGS 84. 


\section{$D_{\mathrm{x}} \quad \mathrm{D}_{\mathrm{x}}$-related structures}

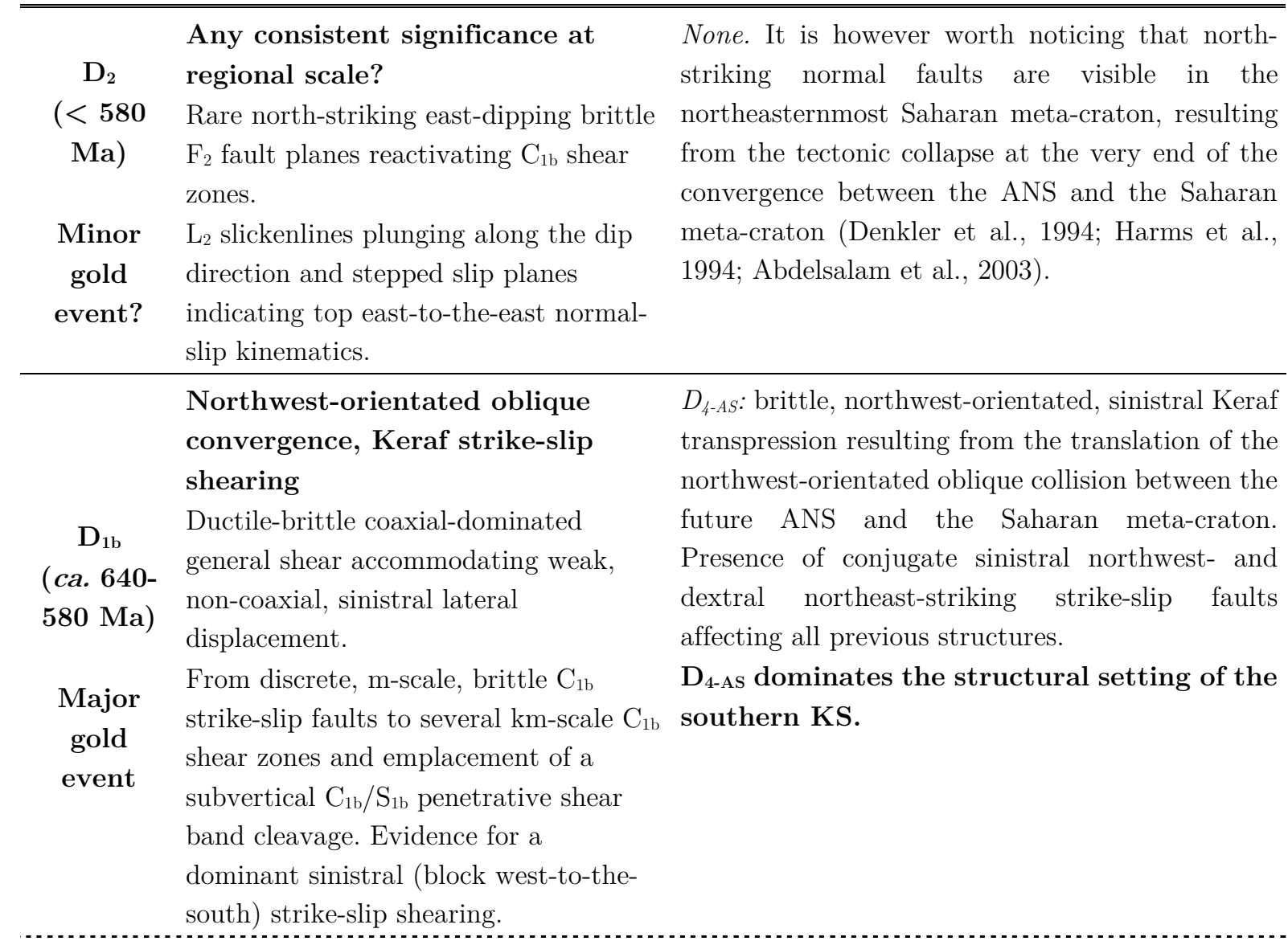

No corresponding structure observed in $D_{3-A S}$ : roughly east-trending, symmetric, open folds our study. superimposed over inherited fold patterns and are mostly visible from satellite imagery (Abdelsalam et al., 1995).

Northwest-orientated oblique convergence, Keraf suturing

Main ductile deformation stage controlling the regional structural framework.

$\mathrm{D}_{1 \mathrm{a}}$ (ca. 700$640 \mathrm{Ma})$
Formation of a roughly north-striking gently east-dipping $S_{1 a}$ penetrative cleavage and gneissic foliation affecting pre- to syn-tectonic meta-

volcanosediments and intrusive bodies, respectively. The lithological contacts of these units also tends to get parallel to $\mathrm{S}_{1 \mathrm{a}}$ planes.
Deformation events

(Ahmed Suliman, 2000)* 
$\mathrm{D}_{\mathrm{x}}$ $D_{x}$-related structures

\section{Deformation events}

(Ahmed Suliman, 2000)*
Rare evidence for a southeast-gently plunging $\mathrm{L}_{1 \mathrm{a}}$ stretching lineation along $\mathrm{S}_{1 \mathrm{a}}$ planes (kinematics?).
$\mathrm{D}_{1 \mathrm{a}}$

(ca. 700-

$640 \mathrm{Ma})$

The related penetrative axial plane cleavage is the main planar fabric observed throughout the area and transposes the primary bedding in metasediments. The gently east-dipping main penetrative cleavage is thought to result from axial plan cleavage development together with a north-striking axial plane folding episode with a subvertical fold axis. Such folds, despite their several $\mathrm{km}$ wavelength according to Ahmed Suliman (2000), have not been observed during this study.

$\mathrm{D}_{1-\mathrm{AS}}$ and $\mathrm{D}_{2-\mathrm{AS}}$ dominate the structural setting of the northern KS.

\footnotetext{
* Deformation episodes in the literature are indexed from $D_{1-A S}$ to $D_{4-A S}$ instead of $D_{1}$ to $D_{4}$ from the original work by Ahmed Suliman (2000), to avoid confusion with deformation indexing in this study. Rough age bracketing for each deformation stage is provided and discussed in the text. Deformation stages that relate to gold mineralization are indicated. Dashed lines indicate that $D_{1 a}$ and $D_{1 b}$ deformation stages are part of a single, prolonged, progressive deformation event whereas plain line indicates that $D_{2}$ is an independent deformation episode.
}

Table 1: Summary of the $\mathrm{D}_{1 \mathrm{a}-} \mathrm{D}_{1 \mathrm{~b}}$ and $\mathrm{D}_{2}$ deformation episodes unraveled across the central Keraf suture. 


\section{Lithologies, structures and gold mineralization of the central Keraf suture}

The geological map of the investigated area is available in Figure 2a. Outcrops discussed in this section and illustrated by Figs. 4 to 8, 10 and 11 are located in Figure 2b. Their geographic coordinates and description are reported in Table 2. A westsouthwest-trending cross-section (extent in Fig. 2a) has been constructed across the studied area and illustrates the relationships between lithology and the main structures (Fig. 3).

\begin{tabular}{llll}
\hline Outcrop ID & Easting $\left(^{\circ}\right)$ & Northing $\left(^{\circ}\right)$ & \multicolumn{1}{c}{ Description } \\
\hline \hline$\# 1$ & 33.298957 & 20.282872 & Meta-andesite \\
$\# 2$ & 33.407881 & 20.434828 & Meta-ash to lapilli tuff \\
$\# 3$ & 33.342592 & 20.299510 & Layered meta-sediments \\
$\# 4$ & 33.003234 & 20.381444 & Marble ridge \\
$\# 5$ & 33.236408 & 20.313202 & Meta-igneous rock \\
$\# 6$ & 33.112477 & 20.285337 & Granitic pluton \\
$\# 7$ & 33.183825 & 20.323270 & Granitic pluton with mafic xenoliths and mingling texture \\
$\# 8$ & 33.297473 & 20.295830 & Meta-sediments \\
$\# 9$ & 33.302725 & 20.284508 & Meta-andesite and meta-diorite \\
$\# 10$ & 33.417345 & 20.474591 & Meta-sediments \\
$\# 11$ & 33.412464 & 20.467093 & Meta-volcanosediments \\
$\# 12$ & 33.139907 & 20.358596 & Meta-diorite \\
$\# 13$ & 33.095032 & 20.343142 & Meta-diorite hosting mineralized en échelon quartz veins \\
& & & (WG03 deposit) \\
$\# 14$ & 33.292320 & 20.280512 & Meta-sediments and mineralized quartz veins \\
& & & (UTM deposit) \\
$\# 15$ & 33.339023 & 20.304732 & Granitoid-hosted mineralized quartz vein network \\
& & & (Central Zone deposit) \\
$\# 16$ & 33.292368 & 20.283458 & Mineralized quartz veins and their proximal off-shoots \\
& & & (UTM deposit) \\
\#17 & 33.236408 & 20.313202 & Distal off-shoot of vertical mineralized veins \\
& & (UTM deposit) \\
\hline
\end{tabular}

Table 2: Geographic coordinates reported as WGS 84 and brief description of the key outcrops discussed in the text. 


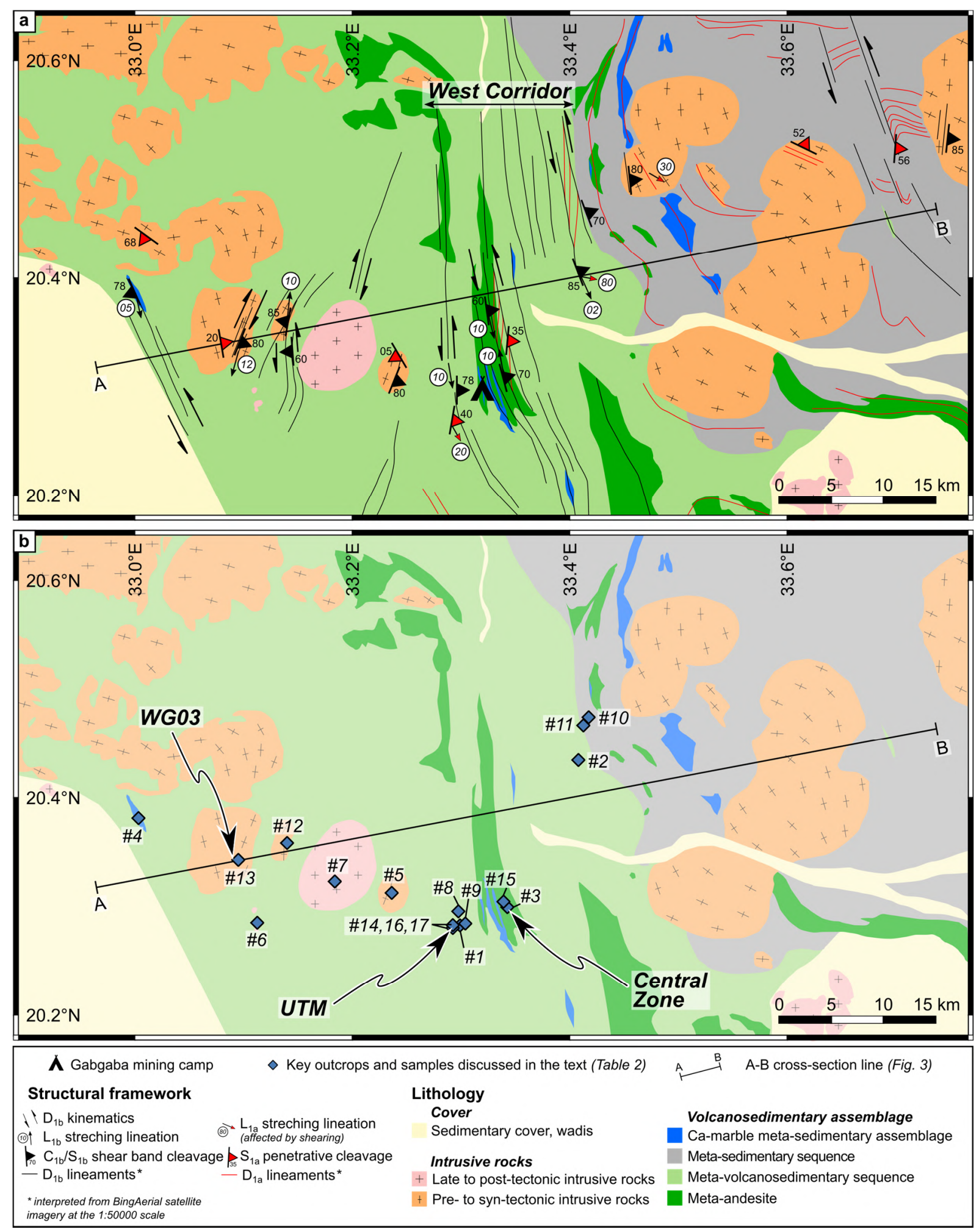

Figure 2: Geological map of the central Keraf suture hosting the Gabgaba gold district, adapted after Managem (2011) and relying on field observations. a Field structural observations and A-B cross-section line (Fig. 3). b Gabgaba gold deposits (UTM, WG03 and Central Zone) and locations of key outcrops and samples discussed in this study. Geographic coordinates are reported as WGS 84. 


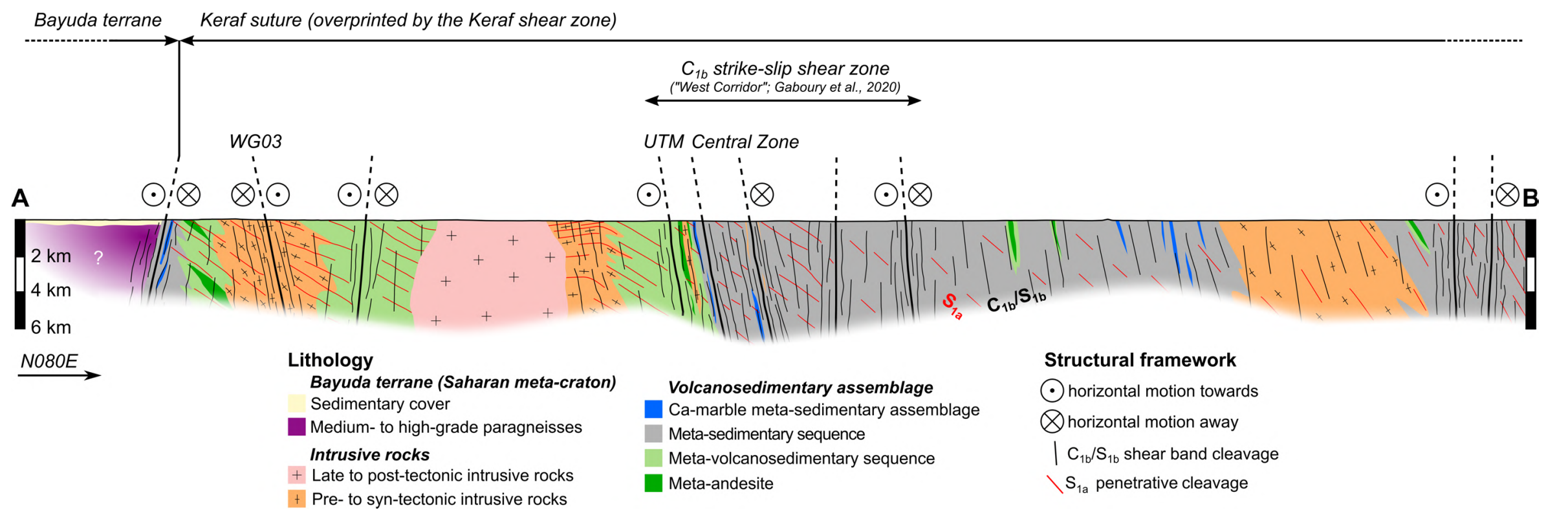

Figure 3: A-B crustal cross-section through the central Keraf suture. See Figure 2 for location. 


\subsection{Lithological framework of the central Keraf suture}

The pre-, syn- and post-tectonic nature of lithologies observed in the central KS is relative to suturing tectonics. The pre- to syn-tectonic meta-volcanosedimentary assemblage is predominant (Figs. 1c, 2a) and is composed of:

(i) A meta-volcanoclastic sequence characterized by low-grade schistose meta-andesite and ash to lapilli tuffs (Fig. 4a, b). Andesite crops out well and its contact with the volcanoclastics is gradual to sharp, parallel to the main penetrative fabric (Fig. 3).

(ii) Meta-sediments which are mostly composed of schistose turbidites. The bedding is visible where silty layers alternate with silty to sandy layers and it is transposed (i.e., its original orientation is completely or nearly completely rotated to the plane of the deformation affecting it) along the main penetrative fabric in most places (Figs. 3, 4c). Meta-sediments are interlayered with meta-volcanoclastic rocks and do not necessarily crop out well. The transition from one unit to another is gradual and difficult to map from regional to outcrop scales (Figs. 1c, 2a, 3). Metaturbidites alternate with Ca-marble ridges that form outcrop- to regional-scale reliefs with sharp contacts parallel to the main penetrative cleavage (Figs. 1c, 2a, 3, 4d).

Pre- to syn-tectonic meta-diorite to tonalite-trondhjemite-granodiorite (TTG) intrusive bodies are enclosed within this extensive meta-volcanosedimentary sequence (Figs. 1c, 2a, 4e). Outcropping pre- to syn-tectonic intrusives are affected by a gneissic foliation that is representative of the regional penetrative fabric (Fig. 3). Their contacts with the surrounding meta-volcanosedimentary rocks are sharp but sheared along the regional penetrative fabric (Figs. 2a, 3, 4e). Post-tectonic coarse granitic intrusive bodies typically crop out as up to tens of mhigh piles composed of up to $10 \mathrm{~m}$-large boulders (Fig. 4f). These rocks show no anisotropy at macroscopic scale. Granite plutons display local heterogeneities with the presence of mafic xenoliths and micro-granular enclaves with feldspar pheno- or xenocrysts (inset in Fig. 4f). Their contacts with surrounding rocks are sharp and cut across every inherited fabric (Fig. 3). 

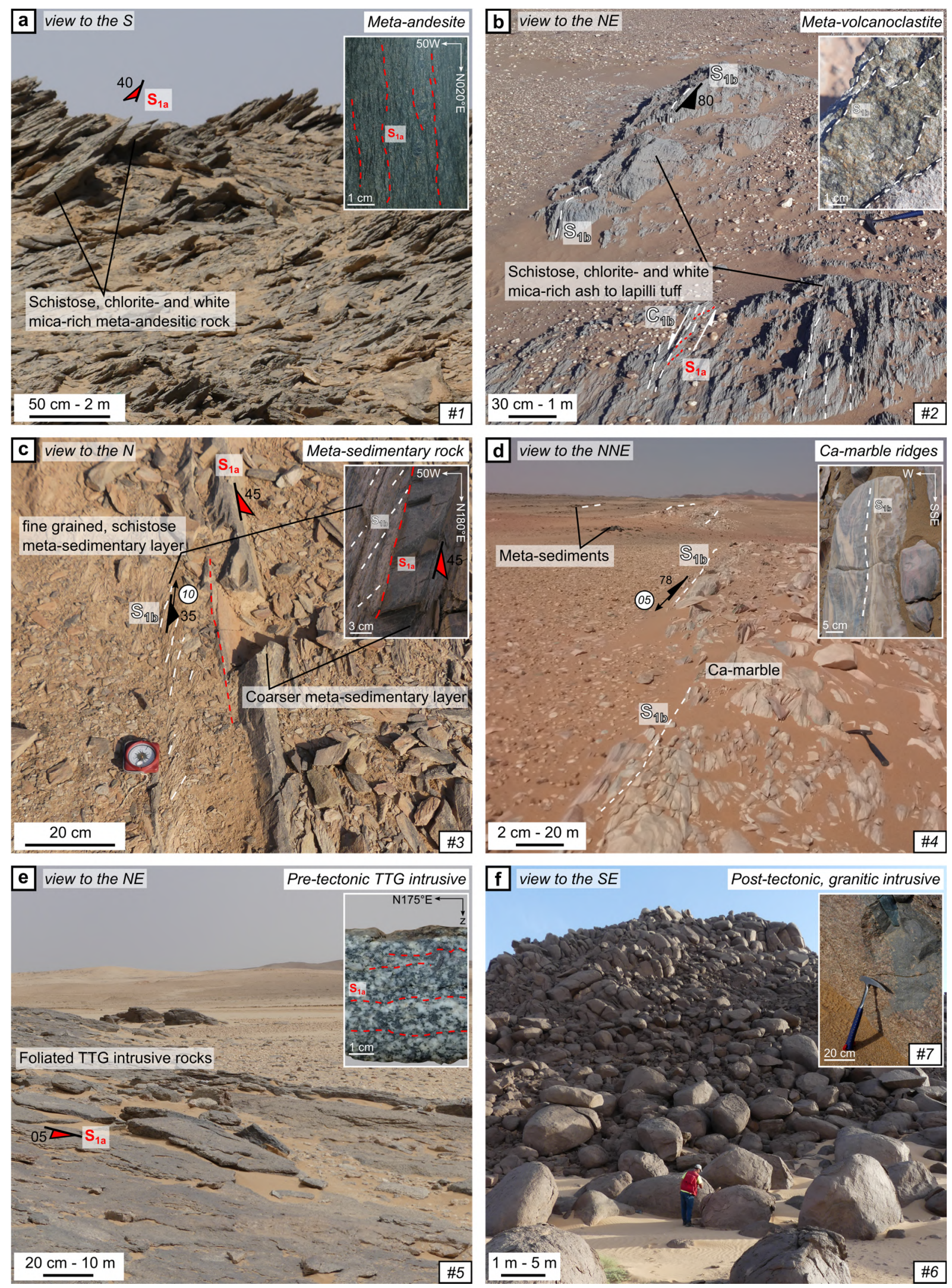

Figure 4: Lithologies of the central Keraf suture. Outcrop locations and structural legend as in Figure 2. a Metaandesite. b Meta-volcanoclastites. c Meta-sediments. d Ca-marble ridges. e Pre-tectonic intrusive rocks. f Post-tectonic intrusive bodies. 


\subsection{Structural framework of the central Keraf suture}

Three deformation stages and phases $\left(\mathrm{D}_{1 \mathrm{a}}, \mathrm{D}_{1 \mathrm{~b}}\right.$ and $\left.\mathrm{D}_{2}\right)$ have been defined. The "stage" vs "phase" nomenclature and indexing of deformation events relies on the distinction between progressive and discrete deformation (Fossen et al., 2019), which is discussed in subsection 4.1. The brittle vs ductile nature of the associated structures, which is a scale-sensitive description (Rutter, 1986; Snoke et al., 1998), is distinguished on field-scale observation. Similar to the approach followed by Perret et al. (2020), such nomenclature is used "to distinguish the dominant manner by which deformation occurs" (Tikoff et al., 2013): brittle deformation for faulting and fracturing and ductile deformation for penetrative fabric development and folding (Twiss and Moores, 2007). Table 1 summarizes $\mathrm{D}_{1 \mathrm{a}^{-}}, \mathrm{D}_{1 \mathrm{~b}^{-}}$to $\mathrm{D}_{2}$-related structures, as well as their correlation with the $\mathrm{D}_{1-\mathrm{AS}}$ to $\mathrm{D}_{4-\mathrm{AS}}$ tectonic history from literature.

\subsubsection{Ductile $\mathrm{D}_{\text {la }}$ deformation stage}

A rare $\mathrm{S}_{0}$ bedding is observed in meta-turbidites, highlighted by compositional layering between coarser-grained meta-greywackes alternating with finer-grained phyllitic beds (Figs. 4c, 5a and b). Considering rare outcrops, $\mathrm{S}_{0}$ is the dominant planar fabric although it can be weakly to moderately crenulated along the northwest-striking $\mathrm{S}_{1 \mathrm{a}}$ crenulation cleavage (Fig. 5a, b).

At the studied area scale, the $\mathrm{S}_{1 \mathrm{a}}$ fabric is the dominant planar fabric and affects every pre- to syn-tectonic lithological units (Fig. 2a). In most places where metasediments crop out, the $\mathrm{S}_{0}$ bedding is hardly visible because its orientation rotates to get parallel, i.e., transposed, to the $\mathrm{S}_{1 \mathrm{a}}$ crenulation cleavage, resulting in a $\mathrm{S}_{0 / 1 \mathrm{a}}$ composite fabric (Figs. 4c, 5a and b). $\mathrm{S}_{1 \mathrm{a}}$ is also the gneissic foliation affecting igneous intrusive bodies and the penetrative cleavage affecting andesitic rocks (Figs. 2a, 4a, 6a and b) and volcanosediments (Figs. 2a, 6c and d). Where not affected by subsequent deformation, the $\mathrm{S}_{1 a}$ penetrative fabric is north-northwest- to north-northeast-striking and gently dips 
eastwards whereas it is subvertical and strikes north-northwestwards where rotated by later $\mathrm{C}_{1 b}$ shear zones (Fig. 6e). A stretching lineation $\mathrm{L}_{1 \mathrm{a}}$ is hardly visible along $\mathrm{S}_{1 a}$ planes and weakly highlighted by stretched clasts in meta-lapilli tuffs (Fig. 6d). Along planes not affected by subsequent deformation, $\mathrm{L}_{1 a}$ gently plunges southeastwards whereas it steepens where $\mathrm{S}_{1 \mathrm{a}}$ orientation gets closer to subsequent $\mathrm{C}_{1 \mathrm{~b}} / \mathrm{S}_{1 \mathrm{~b}}$ shear band cleavage (Fig. 6f). No shear sense indicator is visible.

\subsubsection{Ductile-brittle $\mathrm{D}_{1 \mathrm{~b}}$ strike-slip shearing stage}

$\mathrm{D}_{1 \mathrm{~b}}$ structures range from regional- to outcrop-scale ductile shear zones (Figs. 2a, 3, 6d, 7a, b, and c) to local, discrete brittle faults (Figs. 5c, d, e and f, 6c). Depending on the $\mathrm{D}_{1 \mathrm{~b}}$ strain intensity and the deformed rock rheology, the $\mathrm{C}_{1 \mathrm{~b}} / \mathrm{S}_{1 \mathrm{~b}}$ shear band cleavage (or $\mathrm{C}_{1 \mathrm{~b}}$-type shear band; Passchier and Trouw, 2005) penetrates only the less competent meta-sedimentary rocks. With increasing strain: (i) the regional penetrative fabric $\mathrm{S}_{1 \mathrm{a}}$ is preserved (Fig. 4c) and locally cut across by discrete, subvertical, weakly expressed $\mathrm{C}_{1 \mathrm{~b}}$ strike-slip faults (Figs. 5c, d, e and f, 6c); (ii) ductile-brittle $\mathrm{C}_{1 \mathrm{~b}}$-type shear bands are characterized from outcrop to regional scales (Figs. 2a, 3, 4b, 6d); and (iii) $\mathrm{S}_{1 \mathrm{~b}}$ locally becomes the main penetrative fabric in $\mathrm{C}_{1 \mathrm{~b}}$ shear zones where there is a very low obliquity between $\mathrm{S}_{1 \mathrm{~b}}$ and $\mathrm{C}_{1 \mathrm{~b}}$ planes (Figs. 3, 7c and d). In the latter configuration, lithological contacts and the $\mathrm{S}_{1 \mathrm{a}}$ cleavage have rotated along $\mathrm{C}_{1 \mathrm{~b}}$ planes (Figs. 2a, 3, 5d).

There is evidence for a very limited lateral displacement along $\mathrm{C}_{1 \mathrm{~b}}$ shear zones which does not exceed a few centimeters at the outcrop scale, even in marbles which easily flow under low strain conditions yet (Figs. 2a, 4b, 5e and f, 7a). No discrete individual shear accommodating relatively important lateral offsets has been noticed neither, suggesting that $\mathrm{C}_{1 \mathrm{~b}}$ shear zones are homogeneous. Nevertheless, $\mathrm{C}_{1 \mathrm{~b}}$ shear zones likely accommodate a weak, non-coaxial, strike-slip component (Figs. 2a, 3) as suggested by (i) the relatively short left-lateral offset along $\mathrm{C}_{1 \mathrm{~b}}$ strike-slip shears (Fig. 5c, d, e, f), (ii) $\mathrm{C}_{1 b}$-type shear band asymmetry (Figs. 2a, 6c), (iii) the subtle presence of subhorizontal stepped slip markers along $\mathrm{C}_{1 \mathrm{~b}}$ planes (Figs. 6d, 7c), (iv) drag fold asymmetry in flowing marble layers 
(Fig. 7a, b) and (v) the subhorizontal orientation of the $\mathrm{L}_{1 \mathrm{~b}}$ stretching or biotiteamphibole mineral lineation along the $\mathrm{C}_{1 \mathrm{~b}}$ planes (Figs. 2a, 7b, c and $\mathrm{d}$ ). The $\mathrm{C}_{1 \mathrm{~b}}$ shear zones are mostly subvertical and display two conjugate sets (Fig. 7e, f). The main $\mathrm{C}_{1 \mathrm{~b}}$ strike-slip shears are north-northwest- to north-striking and accommodate sinistral strike-slip shearing (Figs. 2a, 3, 6c, 7d). North-northeast- to northeast-striking conjugate structures are less visible and display dextral kinematics (Figs. 2a, 3, 7e and f), relying on outcrop-scale shear sense indicators described above and deflection of $\mathrm{D}_{1 \mathrm{a}}$-related lineaments visible in satellite imagery within $\mathrm{C}_{1 \mathrm{~b}}$ shear zones (Fig. 2a).

\subsubsection{Late brittle $\mathrm{D}_{2}$ normal faulting phase}

A late, weakly expressed, brittle $\mathrm{D}_{2}$ deformation episode has been identified in the UTM area. It is characterized by the local reactivation of the $\mathrm{C}_{1 \mathrm{~b}}$ shear zones as normal faults (Fig. 8). Shear zones reactivated as normal faults that have been spotted in this study preferentially separate rock units with a strong rheological contrast, e.g., between meta-diorite or granitoid intrusion and meta-volcanosediments (Fig. 8a). $\mathrm{F}_{2}$ faults are north-striking and steeply east-dipping, similarly to the $\mathrm{C}_{1 \mathrm{~b}}$ shear zone orientation in the UTM area (Figs. 2, 8a). Weakly expressed $\mathrm{L}_{2}$ slickenlines plunging along the dip direction and stepped slip features are visible on fault planes and indicate top-to-the-east normal faulting kinematics (Fig. 8b). 

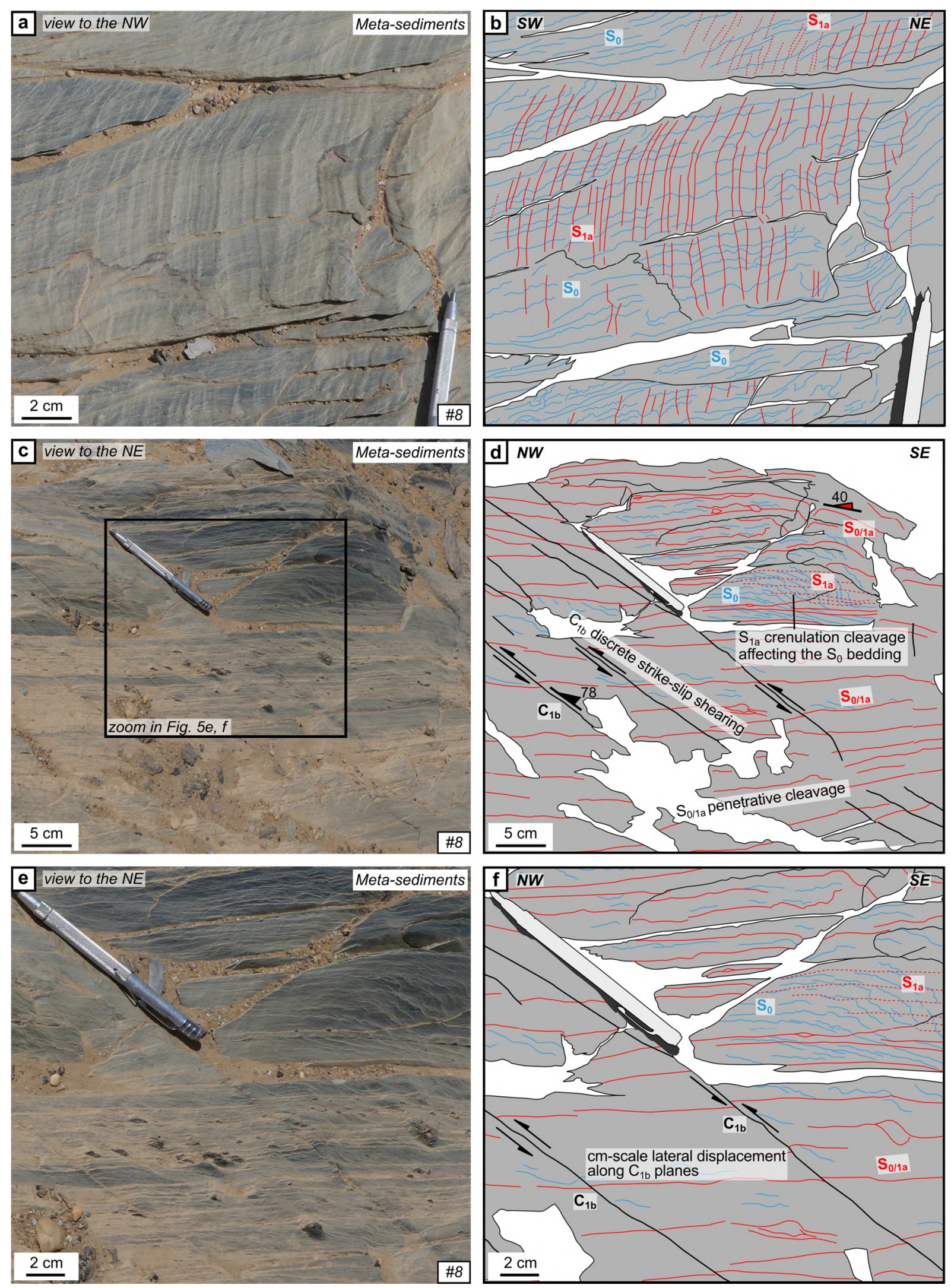

Figure 5: Outcrop expression of the $\mathrm{S}_{0}$ bedding and relationships with the $\mathrm{D}_{1 \mathrm{a}} \mathrm{-} \mathrm{D}_{1 \mathrm{~b}}$ deformation stages in metasediments. See detailed caption on p. 22. 

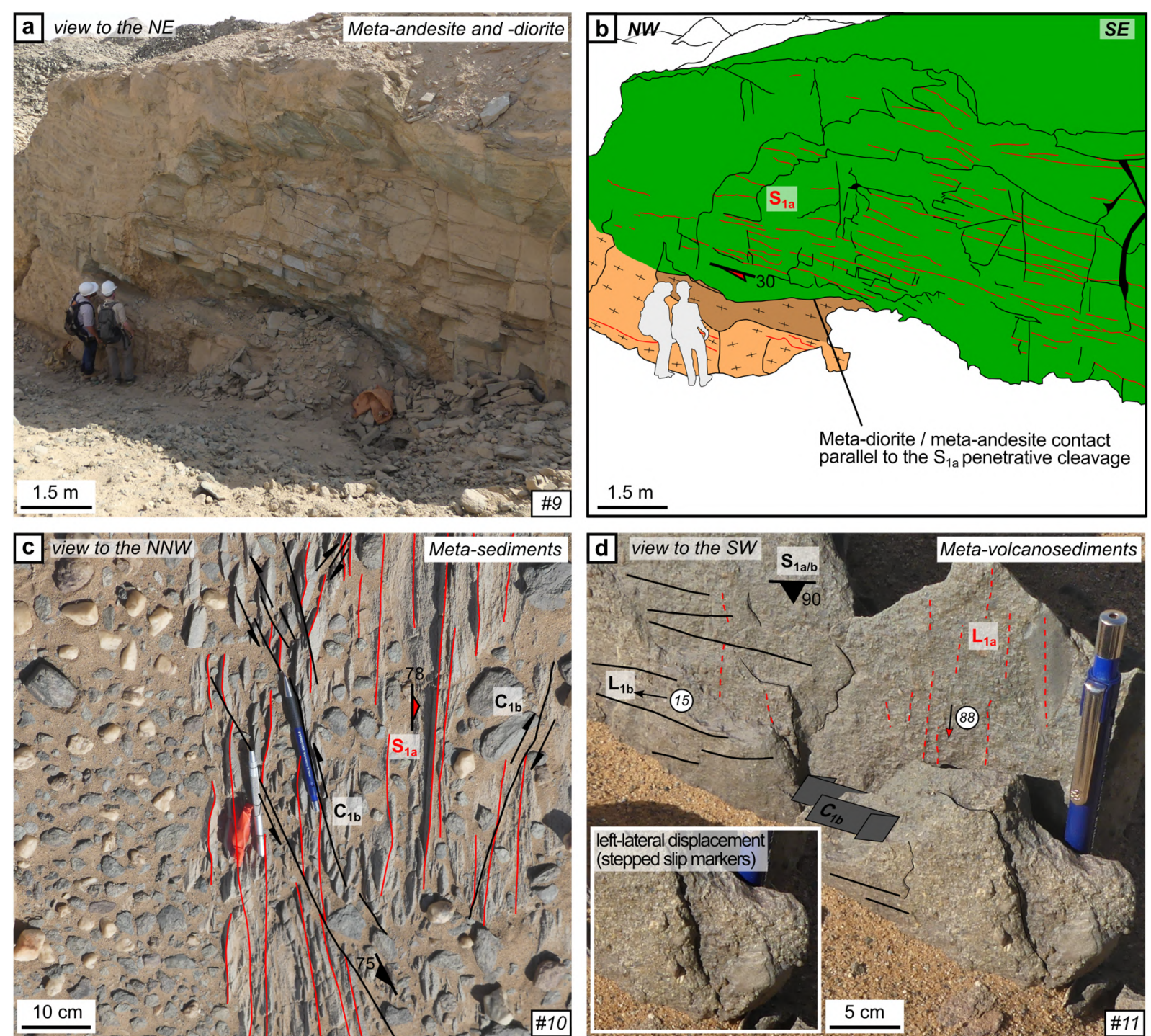

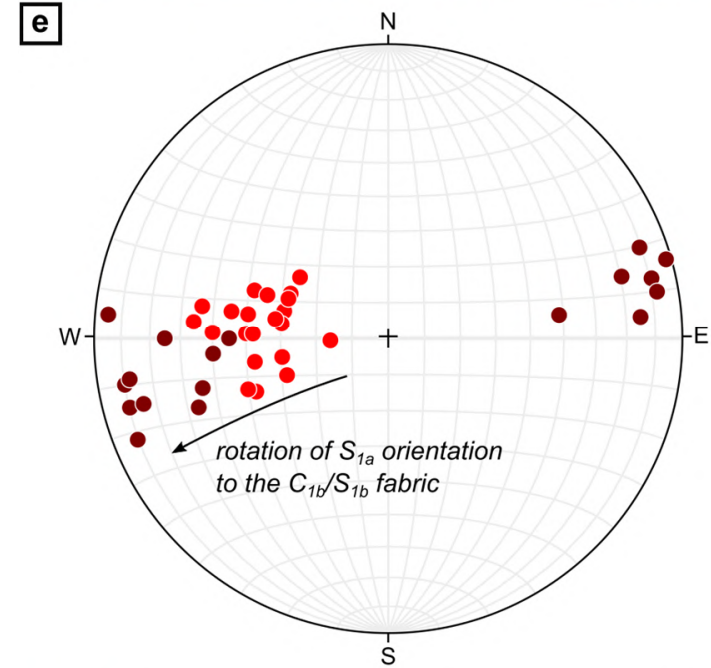

- $S_{1 \mathrm{a}}$ cleavage poles away from $\mathrm{C}_{1 \mathrm{~b}}$ shear zone $(n=22)$ $\mathrm{f}$

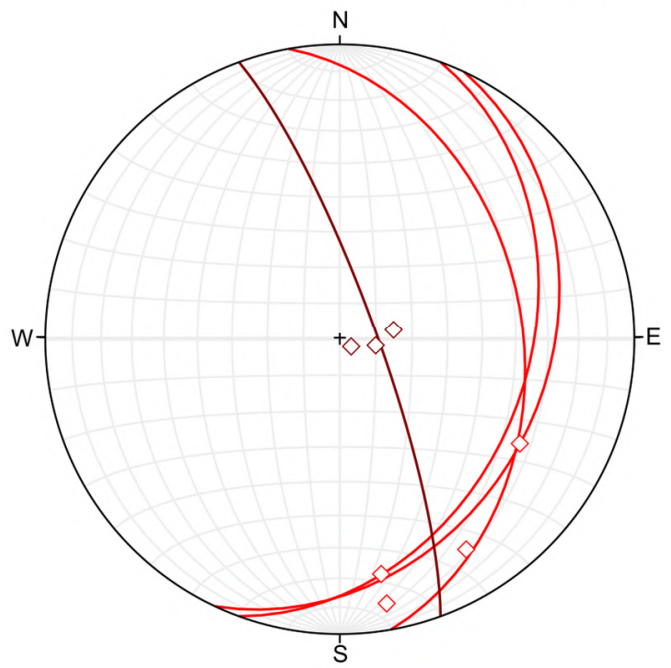

$\diamond \mathrm{L}_{1 \mathrm{a}}$; no evidence for kinematics; away from $\mathrm{C}_{1 \mathrm{~b}}$ shear zone $(n=4)$

- $\mathrm{S}_{1 \mathrm{a}}$ cleavage poles where affected by $\mathrm{C}_{1 \mathrm{~b}}$ shear zone $(n=18) \diamond \mathrm{L}_{1 \mathrm{a}}$; no evidence for kinematics; affected by $\mathrm{C}_{1 \mathrm{~b}}$ shear zone $(n=3)$ Figure 6: Outcrop expression of the regional $\mathrm{D}_{1 \mathrm{a}}$ deformation stage in the Keraf pre-tectonic assemblage rocks, relationships with the $\mathrm{D}_{1 \mathrm{~b}}$ deformation stage and stereonet analysis. See detailed caption on p. 22. 

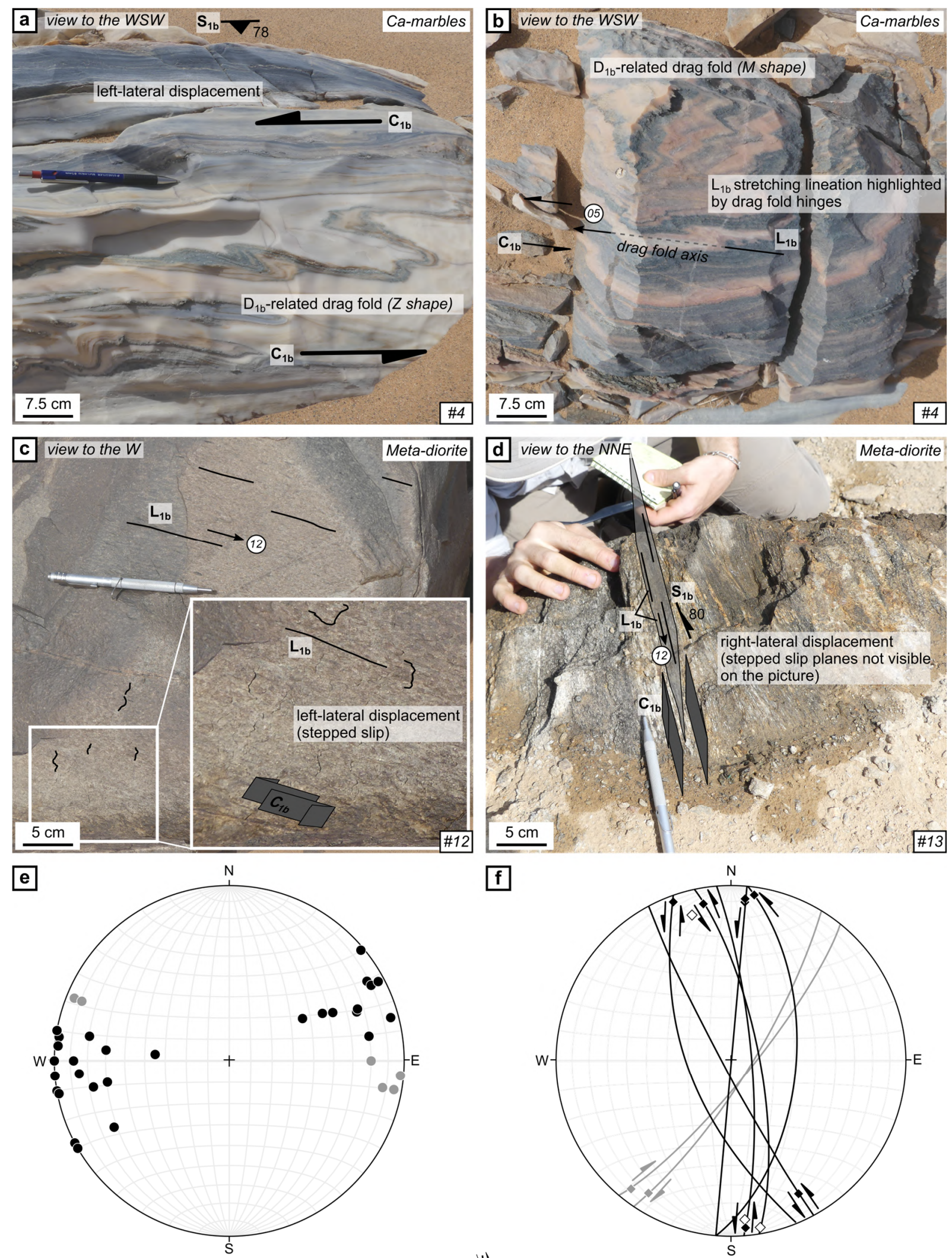

- $\mathrm{C}_{1 \mathrm{~b}} / \mathrm{S}_{1 \mathrm{~b}}$ shear band cleavage or $\mathrm{C}_{1 \mathrm{~b}}$ strike-slip fault poles; NNW-trending $(n=32)$

- $\mathrm{C}_{1 \mathrm{~b}} / \mathrm{S}_{1 \mathrm{~b}}$ shear band cleavage or $\mathrm{C}_{1 \mathrm{~b}}$ strike-slip fault poles; NE-trending $(n=6)$

$\mathrm{f}$

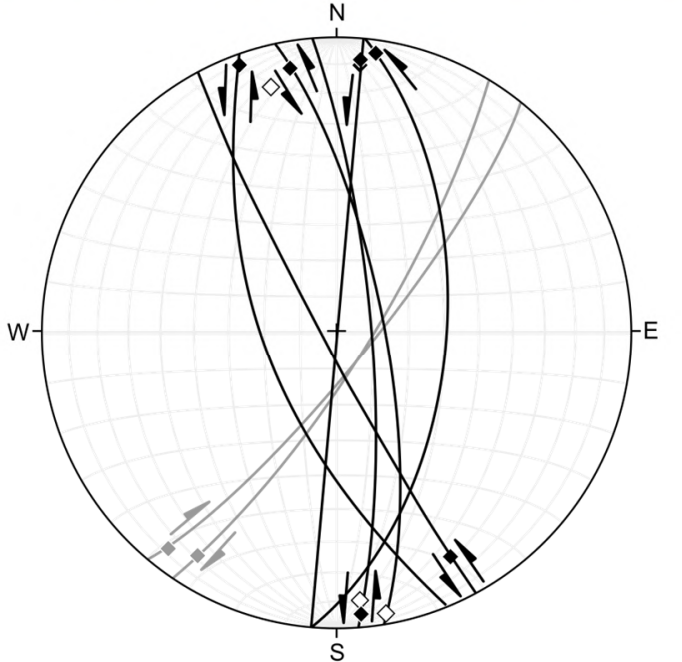

11. $\mathrm{L}_{1 \mathrm{~b}}$; sinistral kinematics; NNW-trending $\mathrm{C}_{1 \mathrm{~b}}$ strike-slip shearing $(n=7)$ $\mathrm{L}_{1 \mathrm{~b}}$; dextral kinematics; NE-trending $\mathrm{C}_{1 \mathrm{~b}}$ strike-slip shearing $(n=2)$ $\diamond \mathrm{L}_{1 \mathrm{~b}}$; No evidence for kinematics $(n=3)$

Figure 7: Outcrop expression of the $\mathrm{D}_{1 \mathrm{~b}}$ deformation stage in the Keraf pre-tectonic assemblage rocks and stereonet analysis. See detailed caption on p. 22. 
Figure 5 (p. 19): Outcrop expression of the $\mathrm{S}_{0}$ bedding and relationships with the $\mathrm{D}_{1 \mathrm{a}}-\mathrm{D}_{1 \mathrm{~b}}$ deformation stages in meta-sediments. Outcrop locations and geological legend as in Figure 2. a and b Outcrop photograph and interpretation. The $\mathrm{S}_{0}$ bedding is the dominant fabric and is weakly to moderately crenulated along the $\mathrm{S}_{1 \mathrm{a}}$ crenulation cleavage. $\mathbf{c}$ and d Outcrop photograph and interpretation. The $\mathrm{S}_{0}$ bedding is strongly rotated to transposed along $\mathrm{S}_{1 \mathrm{a}}$ crenulation planes, resulting into a $\mathrm{S}_{0 / 1 \mathrm{a}}$ penetrative cleavage. This fabric is cut across by discrete, $\mathrm{C}_{1 \mathrm{~b}}$ strike-slip faults displaying sinistral kinematics, although lateral displacement is almost invisible at this scale. Rarer north- to northnortheast-striking dextral $\mathrm{C}_{1 \mathrm{~b}}$ strike-slip faults are also visible. e and f Outcrop photograph and interpretation, zoom of the central part of photograph c. This zoom better illustrates the $<\mathrm{cm}$ to $\mathrm{cm}$-scale left-lateral displacement along north-northwest-striking $\mathrm{C}_{1 \mathrm{~b}}$ strike-slip faults.

Figure 6 (p. 20): Outcrop expression of the regional $D_{1 a}$ deformation stage in the Keraf pre-tectonic assemblage rocks, relationships with the $\mathrm{D}_{1 \mathrm{~b}}$ deformation stage and stereonet analysis. Outcrop locations and geological legend as in Figure 2. $\mathbf{a}$ and $\mathbf{b}$ Outcrop photograph and interpretation. The schistose meta-andesite and foliated meta-diorite are affected by the $\mathrm{S}_{1 \mathrm{a}}$ regional penetrative fabric. Their contact is also parallel to this gently east-dipping fabric. c The $\mathrm{S}_{1 a}$ penetrative fabric is cut across by subvertical $\mathrm{C}_{1 \mathrm{~b}}$-type shear bands. The weak $\mathrm{S}_{1 \mathrm{a}}$ orientation deflection close to $\mathrm{C}_{1 \mathrm{~b}}$ planes indicates a cm-long left-lateral displacement. $\mathbf{d}$ The $\mathrm{L}_{1 \mathrm{a}}$ stretching lineation is weakly highlighted by stretched clasts in steepened $\mathrm{S}_{1 \mathrm{a}}$ planes within a $\mathrm{C}_{1 \mathrm{~b}}$ shear zone. The $\mathrm{S}_{1 \mathrm{a}}$ fabric is transposed along the $\mathrm{C}_{1 \mathrm{~b}} / \mathrm{S}_{1 \mathrm{~b}}$ shear band cleavage. Subhorizontal L $\mathrm{L}_{1 \mathrm{~b}}$ slickenlines associated with sinistral $\mathrm{C}_{1 \mathrm{~b}}$ strike-slip shearing are visible. e $\mathrm{S}_{1 \mathrm{a}}$ distribution in the central Keraf suture. $\mathbf{f} \mathrm{L}_{1 \mathrm{a}}$ distribution in the central Keraf suture.

Figure 7 (p. 21): Outcrop expression of the D1b deformation stage in the Keraf pre-tectonic assemblage rocks and stereonet analysis. Outcrop locations and structural legend as in Figure 2. a and b Marble ridges flow in a ductile way along the steeply east-northeast-dipping $\mathrm{C}_{1 \mathrm{~b}} / \mathrm{S}_{1 \mathrm{~b}}$ shear band cleavage. Internal drag folds highlight sinistral kinematics for the $\mathrm{C}_{1 \mathrm{~b}}$ strike-slip shearing but the lateral displacement is very low, i.e., $<50 \mathrm{~cm}$. $\mathbf{c}$ The presence of a subhorizontal $\mathrm{L}_{1 \mathrm{~b}}$ stretching lineation and stepped slip markers in $\mathrm{C}_{1 \mathrm{~b}}$ planes highlights a left-lateral displacement. $\mathbf{d}$ The main penetrative cleavage is $\mathrm{S}_{1 b}$ which is here parallel to $\mathrm{C}_{1 b}$ orientation. A subhorizontal $\mathrm{L}_{1 \mathrm{~b}}$ stretching lineation and stepped slip markers in $\mathrm{C}_{1 \mathrm{~b}}$ planes highlight a right-lateral displacement, not visible on the photograph. e $\mathrm{S}_{1 \mathrm{~b}}$ and $\mathrm{C}_{1 \mathrm{~b}}$ distribution in the central Keraf suture. $\mathbf{f} \mathrm{L}_{1 \mathrm{~b}}$ distribution in the central Keraf suture.
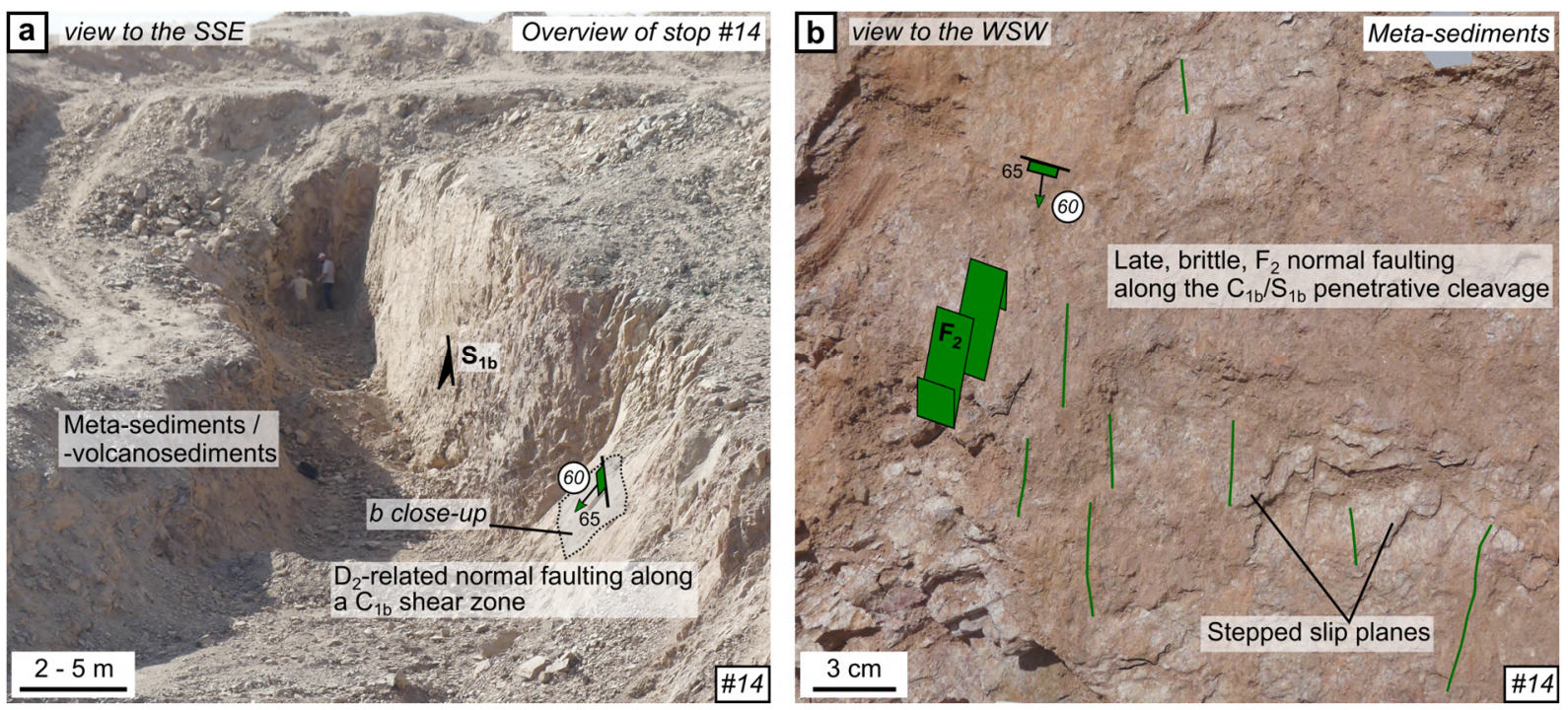

Figure 8: Outcrop expression of the $\mathrm{D}_{2}$ deformation phase in meta-sediments. Outcrop location as in Figure 2. a Overview of the area investigated in Figure $8 \mathrm{~b} . \mathbf{b} \mathrm{C}_{1 \mathrm{~b}} / \mathrm{S}_{1 \mathrm{~b}}$ shear band cleavage is locally reactivated by brittle top-tothe-east $\mathrm{F}_{2}$ normal faulting characterized by dip-plunging $\mathrm{L}_{2}$ slickenline. 


\subsection{Mineralized structures of the Gabgaba gold district}

Deposit-scale geological maps of the WG03, Central Zone and UTM deposits are given in Figure 9a, b and c, respectively. Gold mineralized structures are illustrated from observations on outcrop, drill core and hand samples and thin section (Figs. 10 to 12, respectively). Stereonet structural analyses for the main gold-bearing structures at WG03 and Central Zone deposits are provided in Figure 13.
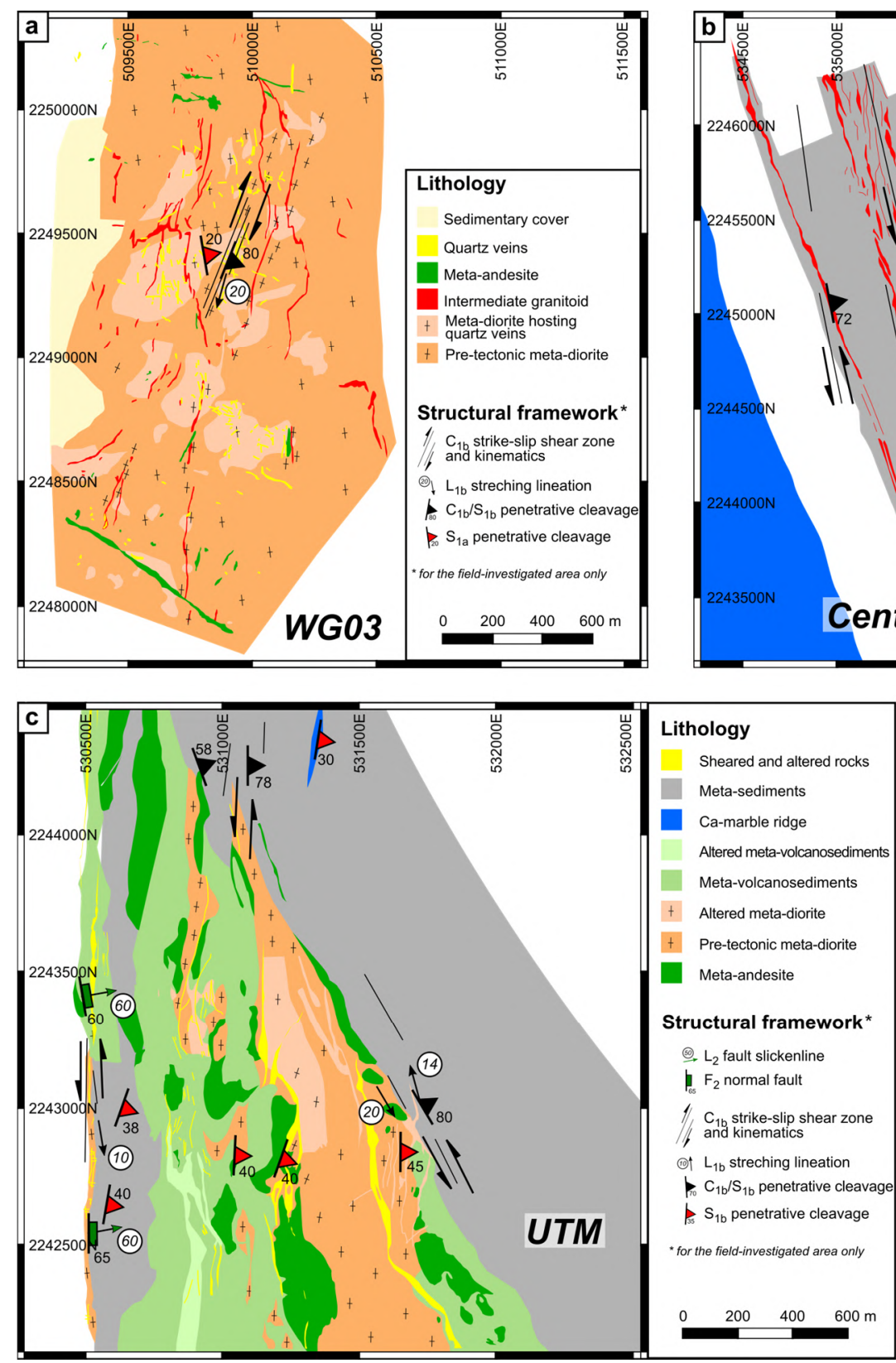

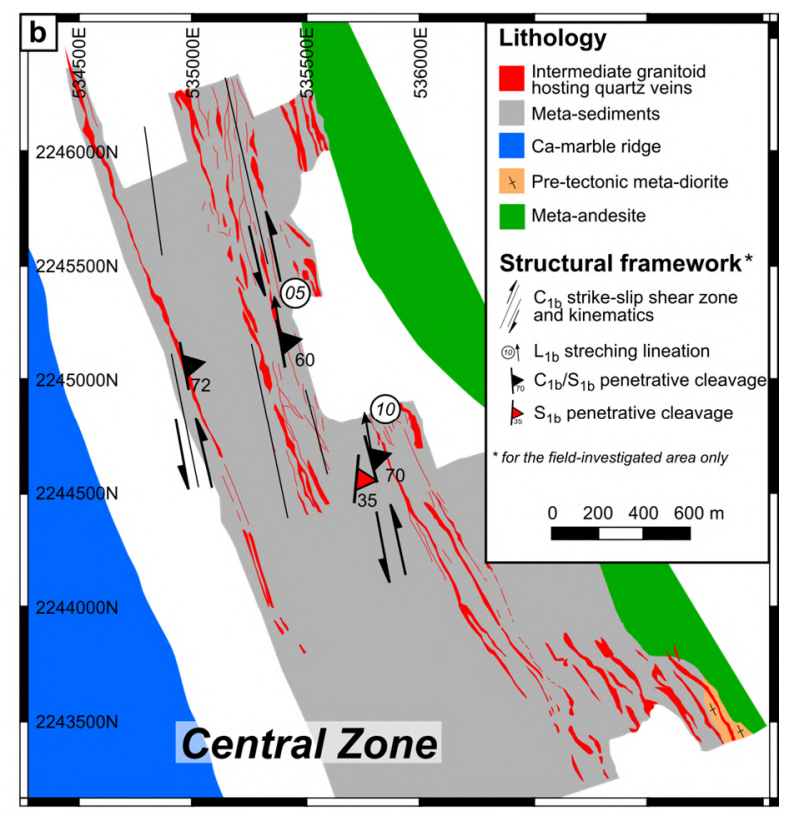

Figure 9: Geological maps of the WG03 (a), Central Zone (b) and UTM (c) deposits belonging to the Gabgaba gold district, adapted after Managem internal reports. Field structural measurements are indicated. Geographic coordinates are reported as WGS 84 / UTM zone $36 \mathrm{~N}$. 


\subsubsection{WG03 gold deposit}

The WG03 deposit is located $\sim 15 \mathrm{~km}$ west to the Gabgaba mining camp (Fig. 2b). It is hosted by a foliated pre-tectonic meta-diorite body affected by the north-northweststriking gently east-dipping $\mathrm{S}_{1 \mathrm{a}}$ regional penetrative fabric (Figs. 9a, 10a). The metadiorite intrusion is also cut across by numerous m-wide, northeast-striking, dextral $\mathrm{C}_{1 \mathrm{~b}}$ shear zones (Figs. 9a, 10a) forming a km-wide shear zone at regional scale (Figs. 2a, 3, 10a). The host rock mineral assemblage mostly consists of amphibole, plagioclase and biotite, with minor quartz, titanite, magnetite and ilmenite (Figs. 11a, 12a and b).

Two gold mineralization events are observed at the WG03 gold deposit. The earliest mineralized features are not visible at outcrop scale. They consist of up to several $\mathrm{cm}$ wide plagioclase-rich mineral assemblage segregated from the meta-diorite host rock (Fig. 11a). It is worth noticing that the use of the term "segregation" is used in a descriptive way below and does not imply anything about magmatic-anatexis petrological processes. The contact between these features and the gangue mineral assemblage is progressive and no sharp limit from one domain to another can be drawn at macroscopic and microscopic scales (Figs. 11a, 12a). The presence of these segregation features is associated with crystallization of plagioclase feldspar phenocrysts up to $10 \mathrm{~cm}$ away within the finer-grained amphibole-plagioclase-biotite mineral gangue (Fig. 11a, right). Pyrrhotite also forms at the transition between segregation features and host rock, associated with biotite and plagioclase (Fig. 12b). Where later gold-bearing structures are not visible, the presence of such plagioclase-rich patches correlates with gold grades ranging from 0.10 up to $1 \mathrm{~g} / \mathrm{t}$ Au (Figs. 11a, 12a and b). However, no free gold grain nor micro-particle has been observed for such samples in thin section.

The subsequent gold-bearing structures are the most frequent at the WG03 deposit and characterized at outcrop scale. They are hydrothermal quartz-rich vein arrays cutting across the $\mathrm{S}_{1 \mathrm{a}}$ gneissic foliation and shaped like Type II en échelon veins (Fig. 10a, b; Bons et al., 2012). This hydrothermal vein set sharply cuts across the meta-diorite 
gangue mineral assemblage and segregation features described above (Figs. 11b, 12c). Free gold grains are coeval with minor carbonation and moderate silicification spreading out from the vein margins (Fig. 12c, d). Gold grades range from $<1$ up to $30 \mathrm{~g} / \mathrm{t} \mathrm{Au}$ where the veins are observed, suggesting that the crosscutting quartz veining is the main gold mineralization event at the WG03 deposit (Figs. 11b, 12c and d). Despite the quartz internal crystal morphology is unclear in veins, the presence of coarse-grained quartz and the en échelon geometry of the vein array suggest that these veins are dilational (Figs. 10b, 11b, 12c). It means that they likely result from precipitation of minerals from fluids circulating in mode I-extensional fractures (Bons et al., 2012). The vein orientation progressively rotates from (i) subhorizontal to (ii) gently northeast-dipping and (iii) subvertical, north-northeast-striking with increasing deformation in lenses between $\mathrm{C}_{1 \mathrm{~b}}$ shear zones, i.e., veins progressively rotate parallel to $\mathrm{C}_{1 \mathrm{~b}}$ planes and get transposed along them (Fig. 13a).

\subsubsection{Central Zone gold deposit}

The Central Zone deposit is located just east to the Gabgaba mining camp, within the several km-wide $\mathrm{C}_{1 \mathrm{~b}}$ shear zone known as the "West Corridor" (Figs. 2a, 3, 9b). There, a subhorizontal stretching lineation $\mathrm{L}_{1 \mathrm{~b}}$ plunges $10-12^{\circ}$ northwards and shear sense indicators characterized the weak, left-lateral strike-slip component of the ductile-brittle shear zone (see above; Fig. 9b).

The gold mineralization corresponds to a well-developed vein system hosted by a network of granitoid intrusions in the Central Zone area (Fig. 9b). Shearing affects their contacts with surrounding meta-sediments (not illustrated in figures) but their inner part is not sheared and no penetrative fabric is visible at any scale (Figs. 10c, 11c and d, 12e). It is unclear whether these intrusions were injected along $\mathrm{C}_{1 \mathrm{~b}}$ planes or are boudinaged and dismembered during $\mathrm{D}_{1 \mathrm{~b}}$ deformation. The exact lithological nature of these granitoids remains unknown due to strong, pervasive sericitization-albitization spreading from vein margins (Fig. 12e). Yet, as the major element composition of the altered 
granitoid is known (59 wt.\% $\mathrm{SiO}_{2}, 19$ wt. $\% \mathrm{Al}_{2} \mathrm{O}_{3}, 8$ wt. $\% \mathrm{Fe}_{2} \mathrm{O}_{3}, 1$ wt.\% $\mathrm{CaO}, 5$ wt.\% $\mathrm{Na}_{2} \mathrm{O}, 1$ wt.\% $\mathrm{K}_{2} \mathrm{O}$ and 4 wt.\% loss of ignition; unpublished data), we can approximate an intermediate to felsic nature for the unaltered protolith. The mineralized veins are a few $\mathrm{cm}$ up to $1 \mathrm{~m}$-wide (Figs. 10c, 11c). Two sets of conjugate, connected veins are separated: the first ones are flat to gently west-northwest- or west-southwest-dipping whereas the second ones are gently east-northeast-dipping (Figs. 10c, 13b). They are composed of a quartz-ankerite-albite assemblage with a zoning from ankerite-albite-rich margins and quartz-rich core (Figs. 11c, 12e). Ankerite and albite crystals in vein display an elongate-blocky morphology perpendicular to vein walls and blocky quartz crystallization occurs as a final sealing stage (Figs. 11c right, 12e; Bons et al., 2012). It suggests that these syntaxial veins are purely dilational. Proximal pyritization of the host granitoids is associated with gold grades of about $0.1-1 \mathrm{~g} / \mathrm{t}$ Au whereas up to $30 \mathrm{~g} / \mathrm{t} \mathrm{Au}$ concentration is reached where free gold is associated with quartz in veins (Figs. 11c and d, 12 e and $\mathrm{f})$.

\subsubsection{UTM gold deposit}

The UTM deposit is located just west to the Gabgaba mining camp, within the "West Corridor" (Figs. 2a, 3, 9c). It is hosted by sheared and strongly chloritized metavolcanosediments and foliated pre-tectonic meta-diorite intrusions (Fig. 9c). Granitoid intrusions similar to the ones described in the Central Zone area are visible along $\mathrm{C}_{1 \mathrm{~b}}$ shear zones in the UTM area (Fig. 10d). There, late, $\mathrm{F}_{2}$ normal faults reactivated $\mathrm{C}_{1 \mathrm{~b}}$ shear zones along lithological-rheological contacts (Figs. 8a, 9c).

Gold-bearing quartz veins are currently being exploited at the UTM deposit. In the field, we were therefore able to approximate the gold potential of veins from how intensively they had been mined. The most important mineralized veins are subvertical, m-wide and formed along lithological-rheological contacts where $\mathrm{F}_{2}$ normal faults are observed (Fig. 10d, e). These veins have never been characterized where $\mathrm{C}_{1 \mathrm{~b}}$ shear zones occur with no evidence for late, normal faulting reactivation. However, the genetic 
association between normal faulting and gold-mineralized veining remains uncertain as no kinematic evidence has been observed directly from the vein walls. Subvertical veins have off-shoots into the gently east-dipping $\mathrm{S}_{1 \mathrm{a}}$ cleavage affecting the surrounding metavolcanosediments, outside from the $\mathrm{F}_{2}$-reactivated $\mathrm{C}_{1 \mathrm{~b}}$ shear zone (Fig. 10f). Off-shoots decrease in width down to a few $\mathrm{cm}$ at several tens of $\mathrm{m}$ away from the main goldbearing, subvertical vein they spread from (Fig. 11e). At first sight, the mineral assemblage in mineralized veins and alteration halo at the UTM deposit is quite similar to what is observed for the Central Zone gold-bearing structures. UTM mineralized veins are quartz-ankerite-rich and somehow zoned with quartz-rich core and ankerite-rich margins (Fig. 11e). Veins are associated with proximal pervasive carbonation and pyritization of host rocks, whatever their lithology (Figs. 10e and f, 11e).

Unfortunately, we cannot go further with the observation of mineralizationdeformation relationships at the UTM deposit. The area is indeed intensively exploited and only comprises very limited outcrops. Very few mineralized vein orientations have been measured and no reliable stereonet analysis is therefore possible. Besides, no observation on drill core and thin section has been made to better characterize relationships between macroscopic to microscopic gold-bearing structures, the related mineral assemblages and associated gold grades at the UTM deposit. 

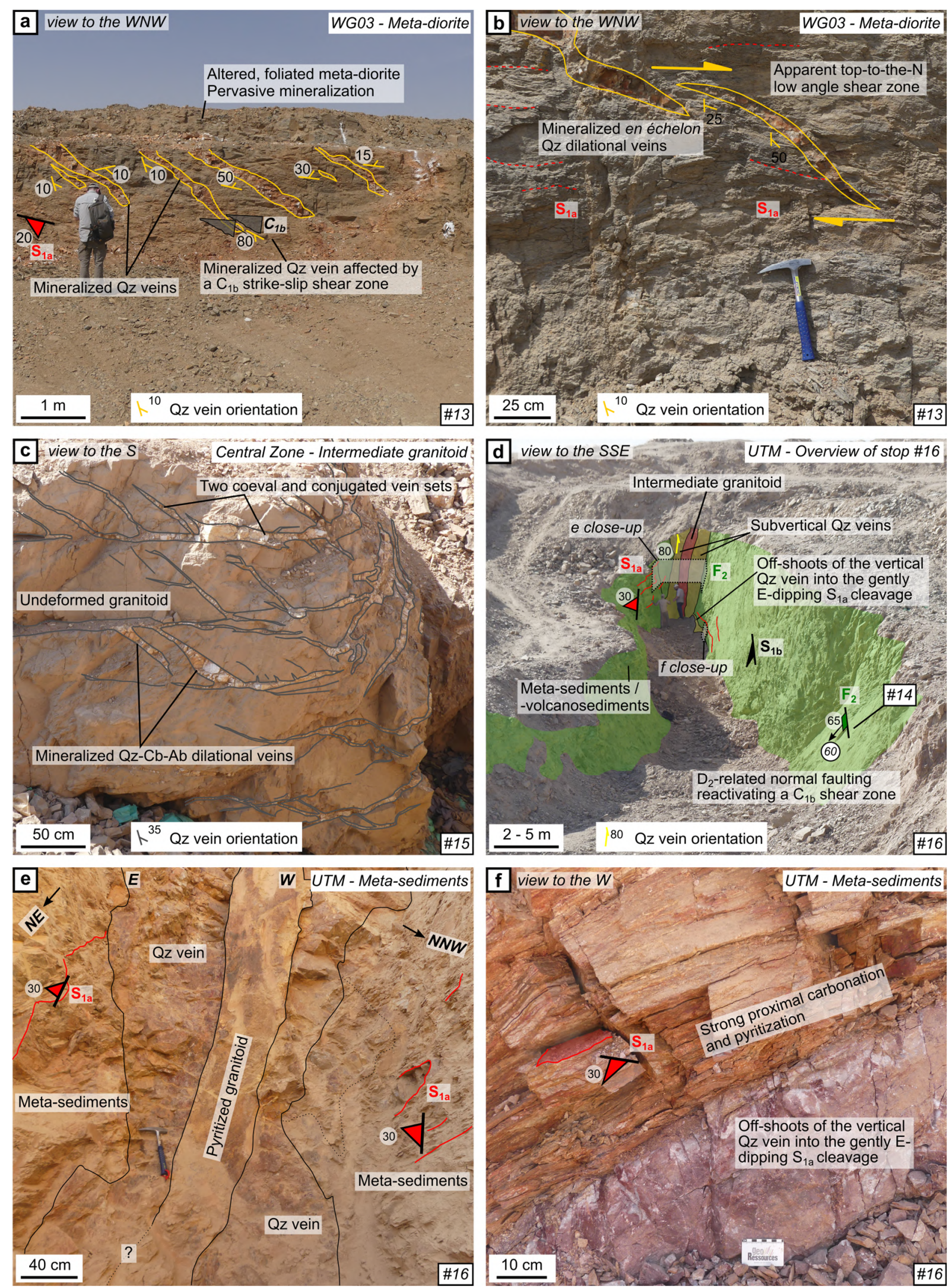

Figure 10: Gold-mineralized structures in outcrop at the Gabgaba gold district. See detailed caption on p. 31. 

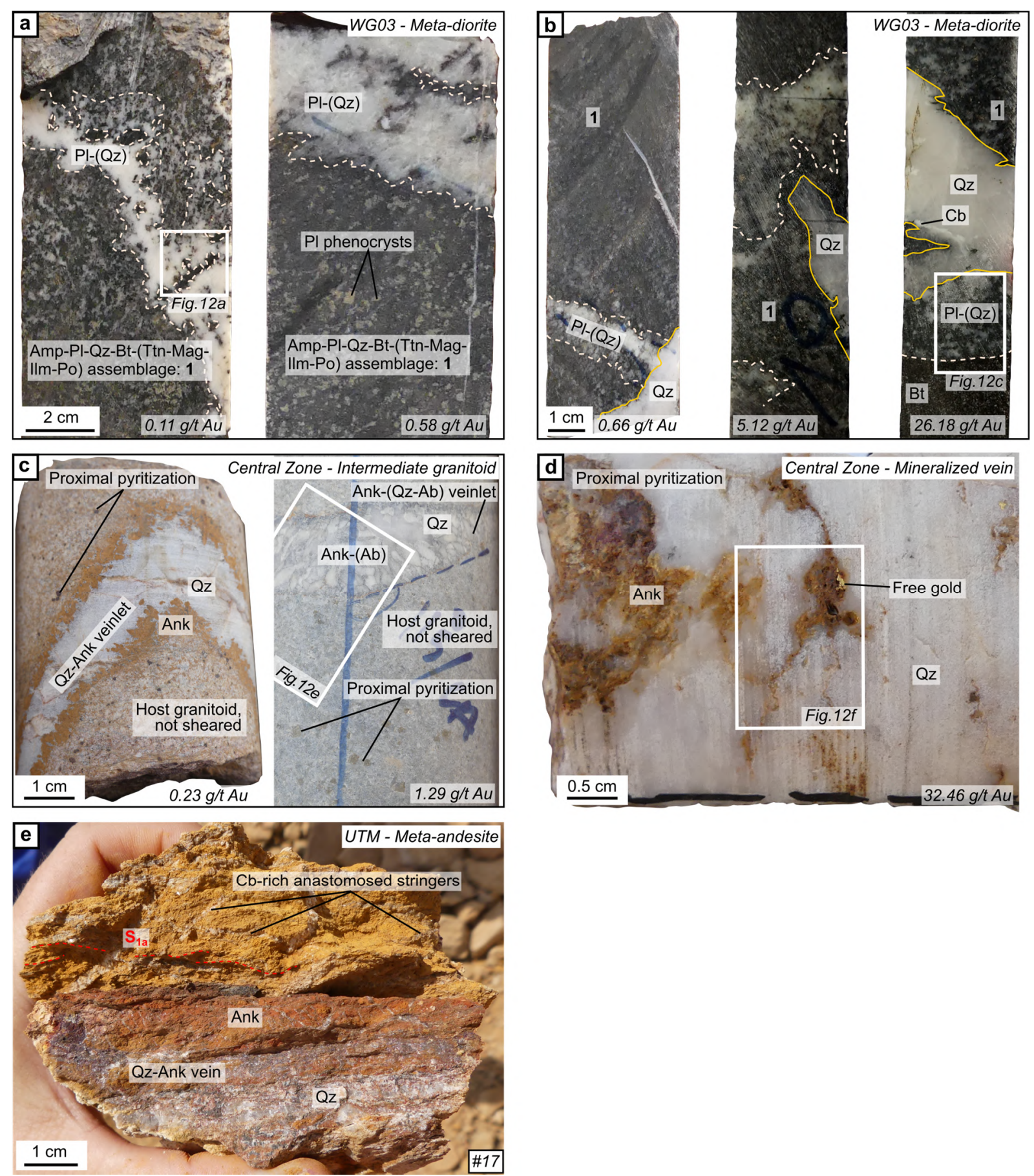

Figure 11: Gold-mineralized structures in drill cores and hand samples at the Gabgaba gold district. See detailed caption on p. 31. 

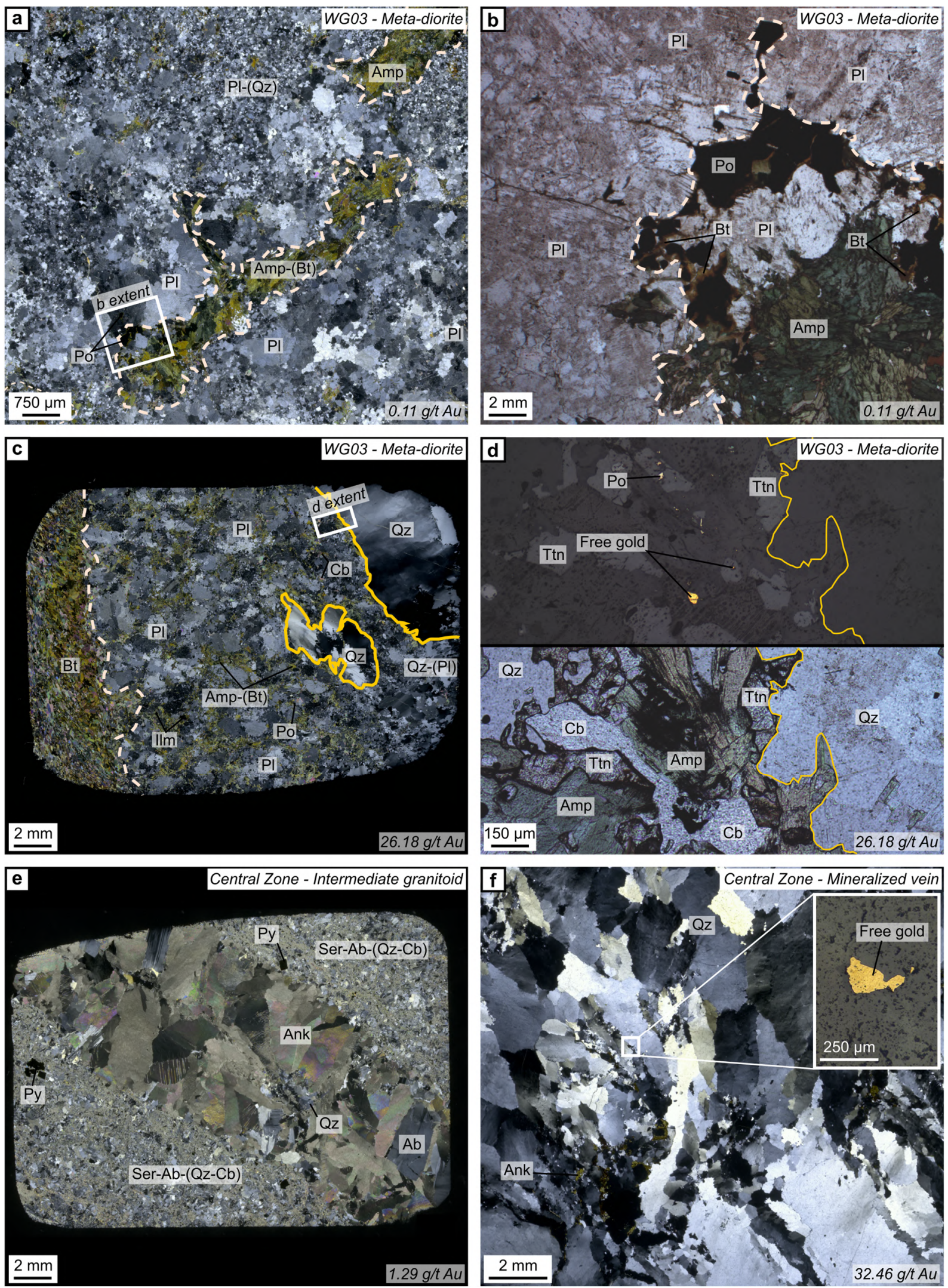

Figure 12: Gold-mineralized structures at the microscopic scale at the WG03 and Central Zone gold deposits. See detailed caption on p. 31. 
Figure 10 (p. 28): Gold-mineralized structures in outcrop at the Gabgaba gold district. Outcrop locations and structural legend are the same as in Figure 2 and mineral abbreviations are $\mathrm{Ab}=$ albite; $\mathrm{Cb}=$ carbonate; $\mathrm{Qz}=$ quartz. WG03 deposit: a Mineralized quartz vein arrays are formed within the pre- to syn-tectonic meta-diorite hosting the WG03 deposit and cut across the penetrative $\mathrm{S}_{1 a}$ gneissic foliation. The $\mathrm{S}_{1 \mathrm{a}}$ fabric and veins are locally rotated along several m-scale $\mathrm{C}_{1 \mathrm{~b}}$ strike-slip shear zones affecting the meta-diorite. b Where undeformed away from any $\mathrm{C}_{1 \mathrm{~b}}$ strikeslip shear zone, the mineralized quartz veins are en échelon dilational veins. Central Zone deposit: c The Central Zone ore is characterized by conjugate quartz-ankerite-albite vein sets cutting across intermediate granitoids, with rare to no lateral extension within the surrounding meta-sediments. UTM deposit: d Overview of the area investigated in Figure 10e and f. An intermediate granitoid intrusion either formed or is deformed along a $\mathrm{C}_{1 \mathrm{~b}}$ strikeslip shear zone affecting meta-volcanosediments. Later, the shear zone has been reactivated as a $F_{2}$ normal fault at the contact between the two rock units. The mineralization is hosted in veins along $\mathrm{F}_{2}$ planes. e The main ore-bearing veins are subvertical. They form where the $\mathrm{C}_{1}$ shear zone has been reactivated as a $\mathrm{F}_{2}$ normal fault. $\mathbf{f}$ Subvertical ore veins have off-shoots into the gently east-dipping $\mathrm{S}_{1 \mathrm{a}}$ fabric, associated with a proximal carbonation and pyritization halo.

Figure 11 (p. 29): Gold-mineralized structures in drill cores and hand samples at the Gabgaba gold district. Outcrop locations are the same as in Figure $2 \mathrm{~b}$ and mineral abbreviations are $\mathrm{Ab}=$ albite; $\mathrm{Amp}=$ amphibole; Ank = ankerite; $\mathrm{Bt}=$ biotite; $\mathrm{Cb}=$ carbonate; $\mathrm{Ilm}=$ ilmenite; $\mathrm{Mag}=$ magnetite; $\mathrm{Pl}=$ plagioclase; $\mathrm{Po}=$ pyrrhotite $; \mathrm{Qz}=$ quartz; Ttn = titanite. Gold grades for WG03 and Central Zone drill core samples are from Managem fire assay analysis database. WG03 deposit: a An early plagioclase-(quartz) segregation assemblage has fuzzy boundaries and no sharp limit with the meta-diorite mineral gangue, mostly composed of amphibole and plagioclase feldspar (simplified into "1" in Figure 11a and b). Plagioclase feldspar phenocrysts are locally visible up to a few centimeters away from the vein wall. The presence of such features in the bulk mineral assemblage is associated with relatively low gold grades between 0.10 and $1.0 \mathrm{~g} / \mathrm{t} \mathrm{Au}$. The extent of Figure 12a is indicated. b Quartz-dominated mineralized veins with sharp contacts cut across the meta-diorite mineral gangue and early segregation features. Their presence is associated with low to higher gold grades (from $<1.0$ up to $30 \mathrm{~g} / \mathrm{t} \mathrm{Au}$ ). The extent of Figure 12c is indicated. Central Zone deposit: c Goldbearing quartz-ankerite-albite veins show a comb texture characterized by albite syntaxial growth perpendicular to vein wall. They are zoned with ankerite-albite crystallization at the vein margins and quartz at the core. A proximal pyritization is widespread through the host granitoid which is not sheared. The approximate extent of Figure 12e is indicated. $\mathbf{d}$ Where free gold is visible at macroscopic scale in dm-wide quartz-(ankerite) mineralized vein, gold grade can reach up to $30 \mathrm{~g} / \mathrm{t}$ Au. The approximate extent of Figure $12 \mathrm{f}$ is indicated. UTM deposit: e Up to several tens of meters away from m-scale, subvertical mineralized veins (Fig. 10f), the width of quartz-ankerite-rich off-shoots into the $\mathrm{S}_{1 \mathrm{a}}$ fabric drastically decreases down to a few centimeters. These mineralized veinlets are zoned, with a quartz-rich core and ankerite-dominated margins. Anastomosed carbonate-rich stringers are formed in the proximal alteration halo associated with these veinlets.

Figure 12 (p. 30): Gold-mineralized structures at the microscopic scale at the WG03 and Central Zone gold deposits. Mineral abbreviations are $\mathrm{Ab}=$ albite; $\mathrm{Amp}=$ amphibole; Ank = ankerite; $\mathrm{Bt}=$ biotite; $\mathrm{Cb}=$ carbonate; $\mathrm{Ilm}=$ ilmenite; Pl = plagioclase; Po = pyrrhotite; Py = pyrite; $\mathrm{Qz}=$ quartz; Ttn = titanite; Ser = sericite. Gold grades for corresponding drill core samples are from Managem fire assay analysis database. WG03 deposit: a (cross-polarized, transmitted light) and $\mathbf{b}$ (plane-polarized, transmitted light) The transition from the amphibole-rich meta-diorite inclusion to the plagioclase-rich segregation zone is diffuse and there is no sharp contact between them where the bulk assemblage is mineralized. Pyrrhotite is associated with biotite in the contact area between these two domains. c (cross-polarized, transmitted light) and $\mathbf{d}$ (above: reflected light; below: plane-polarized, transmitted light) A quartzdominated mineralized vein sharply cuts across the meta-diorite host rock and early plagioclase-rich features. Pervasive silicification spreads from the vein margins. Free gold mineralization is associated with pervasive silicification and carbonation. Central Zone: e (cross-polarized, transmitted light) and f (cross-polarized, transmitted light; inset: reflected light) A mineralized quartz-ankerite-albite vein sharply cuts across the ore-hosting granitoid intrusion strongly sericitized. Pyritization occurred at the vein selvages. Free gold grains are visible within quartz-dominated mineralized veins. 


\section{Interpretation of the tectonic and gold history of the central Keraf suture}

\subsection{Tectonic evolution of the central Keraf suture}

4.1.1. Progressive ductile to ductile-brittle $\mathrm{D}_{1 \mathrm{a}}-\mathrm{D}_{1 \mathrm{~b}}$ Keraf thrusting and strike-slip shearing

The ductile $\mathrm{D}_{1 \mathrm{a}}$ and ductile-brittle $\mathrm{D}_{\mathrm{lb}}$ deformation stages control the structural setting of the central Keraf suture. Below, we interpret them regarding the formation of the KS-KSZ.

The ductile $\mathrm{S}_{1 a}$ penetrative fabric gently dips eastwards between the $\mathrm{C}_{1 b}$ strike-slip shear zones (Figs. 3, 6e). The rare observation of southeast-plunging $L_{1 a}$ lineation and absence of convincing passive markers that would allow assessing the amount and sense of displacement along $\mathrm{S}_{1 a}$ planes suggest that $\mathrm{D}_{1 \mathrm{a}}$ deformation is coaxial-dominated general shear and that its non-coaxial component is weak. The regional penetrative fabric in the central KS is consistently attributed to Keraf suturing convergence in literature ( $\mathrm{D}_{1 / 2-\mathrm{AS}}$ deformation in Fig. 1c and Table 1; Abdelsalam et al., 1998; Ahmed Suliman, 2000; Gaboury et al., 2020). At ANS scale, the significant stretching lineations are southeast-trending and were interpreted as associated with nappe emplacement with a tectonic transport from the southeast or the northwest (Shackleton et al., 1980; Ries et al., 1983; Sturchio et al., 1984; Shackleton, 1986; Bennett and Mosley, 1987; Greiling et al., 1988, 1994). We therefore propose that the ductile $\mathrm{D}_{1 \mathrm{a}}$ deformation stage expresses west- to northwest-verging thrusting during Keraf suturing, given the orientation of $\mathrm{L}_{1 a}$ lineation in the studied area, despite the lack of kinematics evidence.

Ductile $\mathrm{C}_{1 \mathrm{~b}}$ shear zones are subvertical and mostly strike north-northwestwards with left-lateral displacement, although rare north-northeast-striking, dextral shear zones have been observed (Figs. 2a, 3, 7f). These structures are attributed to the KSZ superimposition to the KS in literature, although they have previously been described as brittle structures $\left(\mathrm{D}_{4-\mathrm{AS}}\right.$ deformation in Fig. 1c and Table 1; Abdelsalam et al., 1998; 
Ahmed Suliman, 2000; Gaboury et al., 2020). We therefore suggest that $\mathrm{D}_{1 \mathrm{~b}}$ deformation expresses the late convergent, Keraf sinistral shearing. The formation of rarer conjugate $\mathrm{C}_{1 \mathrm{~b}}$ shear zones may therefore fit with a roughly west-orientated compression. Besides, $\mathrm{D}_{1 \mathrm{~b}}$ deformation is thought to be coaxial-dominated general shear, similarly to what is suggested for the previous $\mathrm{D}_{1 \mathrm{a}}$ stage, as left-lateral displacement along $\mathrm{C}_{1 \mathrm{~b}}$ shear planes does not exceed tens of $\mathrm{cm}$ at the outcrop scale. Despite a presumed change from Keraf thrusting to strike-slip shearing, the formation of the KS-KSZ likely relates to a coaxialdominated $\mathrm{D}_{1 \mathrm{a}}-\mathrm{D}_{1 \mathrm{~b}}$ deformation history thus.

Ductile structures dominate for both $\mathrm{D}_{1 \mathrm{a}}$ and $\mathrm{D}_{1 \mathrm{~b}}$ deformation stages and the orientation of the $\mathrm{S}_{1 \mathrm{a}}$ fabric progressively rotated along ductile $\mathrm{C}_{1 b}$-shear planes in shear lenses at every scale (Figs. 2a, 3 and 6e). There is therefore no field evidence for a temporal break in convergence between the penetrative $\mathrm{D}_{1 \mathrm{a}}$ deformation stage and the formation of $\mathrm{C}_{1 \mathrm{~b}}$ shear zones. Despite there is a change in the expression of the deformation style from thrusting into lateral strike-slip, this may be irrelevant to mention as the magnitude of the non-coaxial component remains unknown for $\mathrm{D}_{1 \mathrm{a}}$ and is thought to be weak for $D_{1 b}$. Besides, there is apparently no drastic change in stress field from $D_{1 a}$ to $\mathrm{D}_{1 \mathrm{~b}}$ deformation, both being consistent with roughly west- to northwest-orientated compression. We therefore consider that the $\mathrm{D}_{1 \mathrm{a}}$ to $\mathrm{D}_{1 \mathrm{~b}}$ deformation stages form a single, progressive, ductile to ductile-brittle deformation episode in a compressional regime (Fossen et al., 2019). Further stress field analysis and geochronological data would be required to confirm the latter hypothesis or prove otherwise.

\subsubsection{Late, brittle, local $\mathrm{D}_{2}$ extension regime and normal faulting}

The tectonic history recorded in the central KS ends with a late, brittle, extensional $\mathrm{D}_{2}$ deformation episode characterized by discrete, north-striking, east-dipping normal faults (Fig. 8). They have only been observed in the UTM area and their spatial extent is limited to less than a hundred meters (Fig. 9c). Normal faults reactivate $\mathrm{C}_{1 \mathrm{~b}}$ shear zones, especially where rheological contrast is enhanced (e.g., between intermediate 
granitoid or meta-diorite intrusions and meta-volcanosediments). If these normal faults are certainly post-KSZ, their significance at regional scale is likely limited.

\subsection{Gold mineralization events of the central Keraf suture}

The mineralization-deformation relationships observed at the WG03, Central Zone and UTM deposits suggest that several mineralization events contributed to the overall gold endowment of the Gabgaba district. They are interpreted in terms of relative timing regarding the central KS tectonic evolution below.

\subsubsection{Minor, low-grade, pre- $\mathrm{D}_{\text {la }}$ gold event (WG03 deposit)}

The first gold event characterized is limited to the WG03 deposit. It consists in plagioclase-rich segregation zones within the amphibole-dominated mineral gangue of the ore-hosting meta-diorite (Figs. 11a, 12a and b). There is no sharp boundary between these two domains and plagioclase feldspar is more or less abundant in both of them (Figs. 11a, 12a and b). These observations suggest that the segregation features may derive from magmatic-hydrothermal processes during the crystallization of the host metadiorite rather than later hydrothermal processes. Similar textures were indeed observed for late magmatic "pegmatitic veins" at the magmatic-hydrothermal Cheechoo gold deposit, Canada (Fontaine et al., 2018; Turlin et al., 2019). However, additional work on fluid nature, composition of plagioclase feldspar and textural description must be carried out to better interpret the magmatic, magmatic-hydrothermal or hydrothermal nature of this mineralizing event. In this study, we only suggest that the first gold event recorded at the Gabgaba gold district is synchronous with pre-tectonic magmatism and therefore predates the regional $\mathrm{D}_{1 \mathrm{a}}$ deformation stage.

Gold grades associated with these segregation features range between $0.1-1 \mathrm{~g} / \mathrm{t} \mathrm{Au}$ and it has been checked in microscopy that gold mineralization is not related to subsequent micro-fractures bringing some gold later in the deformation history. The 
absence of free gold associated with these features therefore suggests that gold is likely structurally bound in the lattice or occurs as nano-inclusions in other minerals, such as sulfides inclusions (e.g., Cook and Chryssoulis, 1990; Reich et al., 2005; Hough et al., 2011; Deditius et al., 2014; Pokrovski et al., 2019; Combes et al., 2021). The only sulfide mineral observed is pyrrhotite which crystallizes at the transition between plagioclaseand amphibole-rich domains (Fig. 12a, b). Further analytical work such as LA-ICP-MS on sulfide should be carried out to test if invisible gold is trapped in pyrrhotite or not.

4.2.2. Major, high-grade, early to syn- $\mathrm{D}_{1 \mathrm{~b}}$ gold event (WG03 and Central Zone deposits)

The main gold-bearing structures at the WG03 deposit are quartz-rich, en échelon veins crosscutting the $\mathrm{S}_{1 \mathrm{a}}$ gneissic foliation and associated with free gold mineralization and up to $30 \mathrm{~g} / \mathrm{t}$ Au grades (Figs. 10a and b, 11b, 12d). The sigmoidal shape of the veins in cross section view, their probable dilational nature and the flat to gently north-dipping orientation of these veins in the least deformed parts of meta-diorite lenses between $\mathrm{C}_{1 \mathrm{~b}}$ shear zones suggest that mineralized veins formed initially along top-to-the-north low angle shear zones (Figs. 10b, 12c, 13a, 14a). This interpretation relies on assuming that the vein opening is controlled by a north-orientated subhorizontal principal stress as indicated by the direction where en échelon vein tips point (Fig. 10b). However, there is no way to be certain that the vein geometry indicates the principal stress directions at the time when they formed as they must have been subsequently rotated at some extent in $\mathrm{C}_{1 \mathrm{~b}}$ shear lenses. Where veins are more affected by $\mathrm{D}_{1 \mathrm{~b}}$ strike-shearing, their orientation rotates counter-clockwise within the shear lenses, resulting in sigmoidal shapes in the horizontal plane (Figs. 13a, 14a). Veins are even transposed along north-northeaststriking subvertical $\mathrm{C}_{1 \mathrm{~b}}$ shear veins where rotation has been the most intense (Figs. 13a, 14a). We therefore suggest that gold-bearing veining at WG03 postdates the $\mathrm{D}_{\text {la }}$ stage and occurred early during the $\mathrm{D}_{1 \mathrm{~b}}$ stage. The vein geometry model illustrated in Figure 14a could indeed fit with the presence of gently dipping extensional zones in an overall 
strike-slip regime if an extensional jog between $\mathrm{C}_{1 \mathrm{~b}}$ shear zones happens to be characterized. However, the $\mathrm{C}_{1 \mathrm{~b}}$ shear zone traces are not well constrained at depositscale and step-over sites have not been recognized in the field (Fig. 9a). If further work is required to answer these questions, the main gold event at WG03 is likely part of the progressive deformation leading to the formation of the KSZ anyway.

Regarding the Central Zone deposit, given the granitoid array geometry and the fact that their contacts with surrounding meta-sediments are sheared, their intrusion likely predated their boudinage and dismembering along $\mathrm{C}_{1 \mathrm{~b}}$ planes during the early $\mathrm{D}_{1 \mathrm{~b}}$ deformation, i.e., ductile formation of the KSZ, under a northwest-orientated compressional regime (Fig. 14b). Free gold-bearing veins (up to $30 \mathrm{~g} / \mathrm{t} \mathrm{Au}$ ) preferentially cut across the granitoid intrusions because of their enhanced competency regarding the surrounding meta-sediments (Figs. 10c, 11c and d). The characterization of two sets of conjugate, connected, purely dilational veins which are flat to gently dipping eastwards or westwards indicates their formation occurred in a compressional regime. As the veins show no shear component, it is possible to reconstruct the finite main strain directions associated with their formation, provided that deformation is coaxial (Fig. 14b). The latter assumption is reliable as the $\mathrm{D}_{1 \mathrm{a}}-\mathrm{D}_{1 \mathrm{~b}}$ deformation controlling the structural setting of the central KS is interpreted to be coaxial-dominated general shear, despite a weak non-coaxial, strike-slip component must be considered for $\mathrm{D}_{1 \mathrm{~b}}$. In the proposed stereonet analysis, veining at Central Zone results from a south-southeast-orientated, subhorizontal shortening direction (Fig. 13b). It fits with the northwest-orientated compressional regime related to the KSZ strike-slip shearing: assuming that veins were formed in response to the latter compressional regime, they may look like the principal shortening direction is south-southeast-orientated due to clockwise rotation with sinistral shearing. 
We therefore suggest that Central Zone gold-mineralized veining occurred during $\mathrm{D}_{1 \mathrm{~b}}$ sinistral shearing and formation of the KSZ second-order "West Corridor" (Fig. 14b).
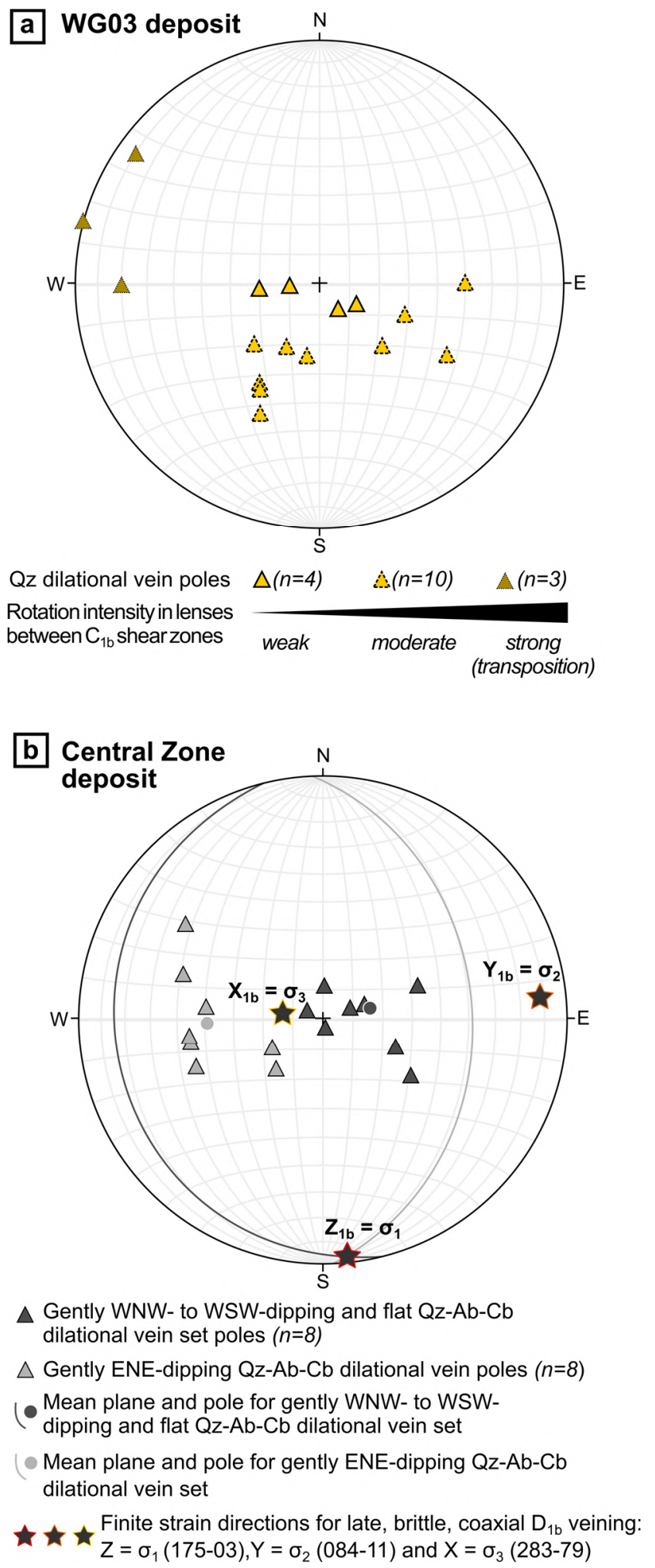

Figure 13: Stereonet analysis of the main gold-mineralized structures at the Gabgaba gold district. Mineral abbreviations are $\mathrm{Ab}=$ albite; $\mathrm{Cb}=$ carbonate; $\mathrm{Qz}=$ quartz. a Crosscutting quartz-dominated mineralized veins at the WG03 deposit. b Gold-bearing quartz-ankerite-albite veins hosted in granitoids at the Central Zone deposit. 

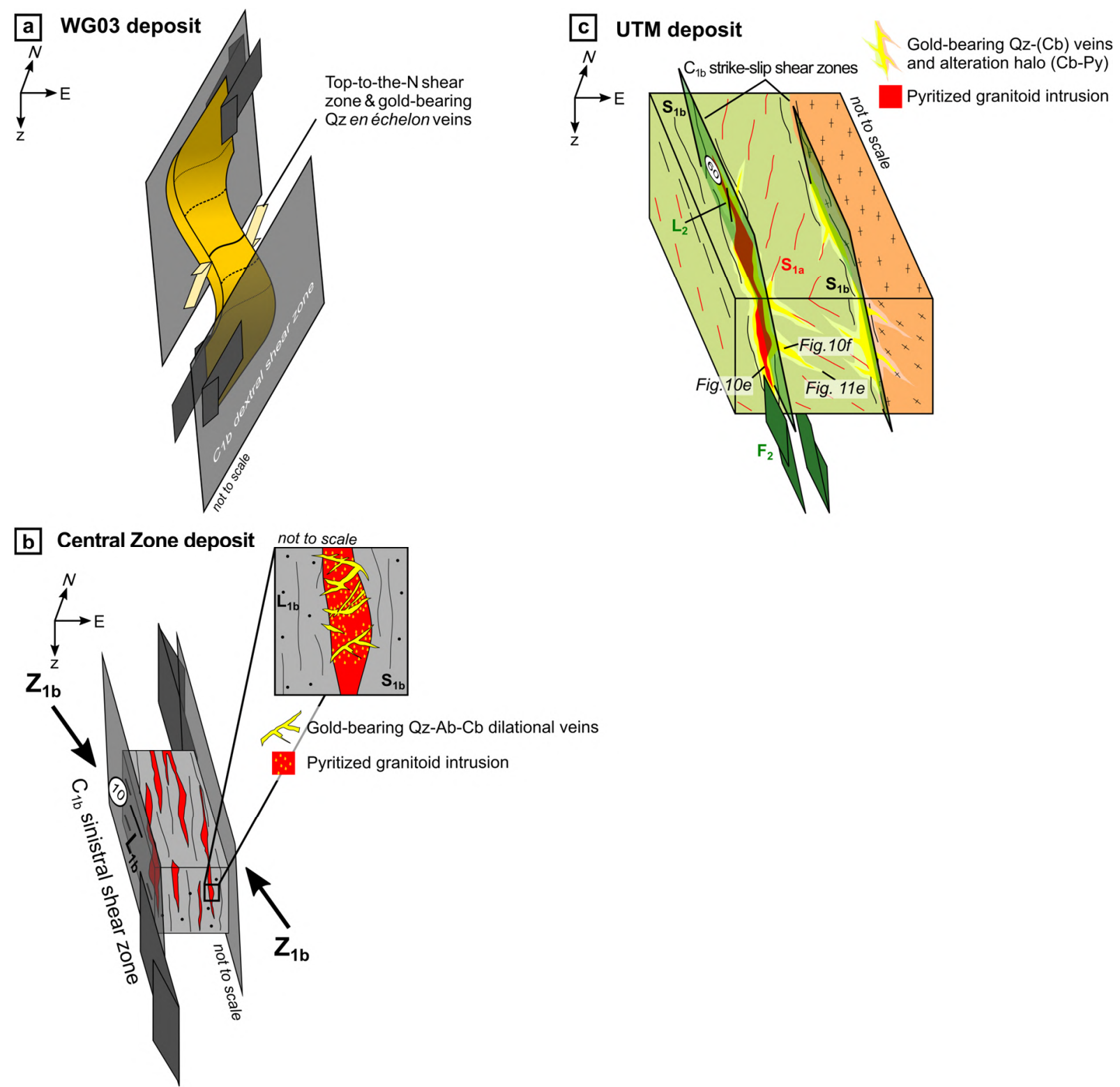

Figure 14: Tectonic interpretation for the formation of the main gold-bearing structures at WG03 (a), Central Zone (b) and UTM (c) deposits. The interpreted location of mineralized structures illustrated in Figs. 10e and $\mathrm{f}$ and $11 \mathrm{e}$ is indicated in $\mathbf{c}$.

The WG03 and Central Zone deposits therefore highlight that a major gold event relates to progressive, ductile-brittle Keraf shearing in the central KS. According to gold grades, structure dimensions and density throughout deposit areas, the gold fertilization associated with this event is likely way higher than the gold budget represented by the early, pre- $\mathrm{D}_{\text {la }}$ gold event defined at the WG03 deposit. However, we cannot conclude whether if $\mathrm{D}_{1 \mathrm{a}}$-related gold results from (i) a new gold input in the system, (ii) the strong remobilization and local re-concentration of former gold, (iii) or a combination of both. 


\subsubsection{A late, syn- $\mathrm{D}_{2}$ gold event (UTM deposit)?}

Despite limited observations of deformation-mineralization relationships for the UTM deposit, we attempted to suggest a mineralization model for this deposit (Fig. 14c). The major gold-bearing veins currently exploited there are subvertical and formed along $\mathrm{C}_{1 \mathrm{~b}}$ shear zones, only where they are reactivated as normal faults during the late brittle $\mathrm{D}_{2}$ extensional deformation event characterized in the UTM area (Figs. 9c, 10d). The formation of these faults is favored where rheological contrast is strong, especially at contacts between rock units of variable competency, e.g., granitoids and meta-sediments (Figs. 9c, 10d). We assume that fluid flow circulation and veining occurred along normal fault plane reactivation in an extensional regime. Besides, we propose that the inherited $\mathrm{S}_{1 \mathrm{a}}$ cleavage affecting surrounding meta-sediments is a very permeable fabric along which mineralizing fluid flow easily spread away from the fault. This mechanism would account for the presence of vein off-shoots and alteration halo into the $\mathrm{S}_{1 \mathrm{a}}$ fabric up to tens of $\mathrm{m}$ away from the main, subvertical veins (Figs. 10d and f, 11e, 14c). However, we lack key evidence to justify the genetic relationship between $F_{2}$ normal faults and subvertical veining as no normal-slip kinematic indicator is visible on vein walls. In addition, the very local extent and discrete manifestation of the $\mathrm{D}_{2}$ deformation episode, limited to the UTM area, contrast with the strong gold endowment of the UTM deposit (see section $3)$.

Besides, it is worth noticing that the vein mineral assemblage dominated by quartz and carbonate, together with proximal pyritization, is quite similar to what is observed at the Central Zone deposit. Host lithologies are somehow the same as well, despite metadiorite and schistose andesite are more abundant in the UTM area (Fig. 9b, c). We could thus legitimately wonder whether if these two deposits relate to the same mineralization event or not. We decided to separate them as the rheological control on mineralization is not expressed in the same way. At Central Zone, mineralized veins preferentially formed within granitoid intrusions deformed along $\mathrm{C}_{1 \mathrm{~b}}$ shear zones whereas veins never 
cut across the most competent plutonic units at UTM. Post- $\mathrm{D}_{1 \mathrm{~b}}$ deformation should therefore be considered prior to or syn-veining at the UTM deposit to justify such a change in structural-rheological control on mineralization. Nevertheless, similarities between UTM and Central Zone deposits raise the possibility that the gold event characterized at the UTM deposit may overprint and/or result from remobilization of the major, syn- $\mathrm{D}_{1 \mathrm{~b}}$ mineralized structures.

\section{Discussion}

Relying on our interpretation of the tectonic and gold history of the central Keraf suture (section 4), we now discuss similarities and differences with previous models and how the described deformation-mineralization events fit into the geodynamical evolution of the western Nubian shield.

\subsection{Reappraisal of the tectonic setting of the central Keraf suture}

\subsubsection{Towards a simplified and unified regional-scale tectonic history}

Our study proposes that the central KS structural framework is dominated by progressive deformation with the succession of $\mathrm{D}_{1 \mathrm{a}}$ and $\mathrm{D}_{1 \mathrm{~b}}$ stages, expressing the formation of the KS and KSZ, respectively, in a roughly west- to northwest-orientated compressional regime. Despite a change in plunge value, $\mathrm{L}_{1 \mathrm{a}}$ and $\mathrm{L}_{1 \mathrm{~b}}$ lineations are mostly north-northwest- to northwest-striking (Figs. 6f, 7f). These lineations have already been identified in the ANS and Mozambique belt southwards (Abdelsalam and Stern, 1996b and references therein) and were further considered as indicating the direction of plate motion during Gondwana assembly (Shackleton and Ries, 1984). Our $\mathrm{D}_{1 \mathrm{a}}-\mathrm{D}_{1 \mathrm{~b}}$ model is therefore in agreement with previous studies suggesting that the formation of the KS and KSZ occurred in a prolonged, northwest-orientated, oblique convergence tectonic setting (Abdelsalam et al., 1995 , 1998; Ahmed Suliman, 2000). Rotation of the regional $\mathrm{S}_{1 a}$ penetrative cleavage and early- $\mathrm{D}_{1 \mathrm{~b}}$ ore en échelon veins of the WG03 deposit in shear 
lenses between $\mathrm{C}_{1 \mathrm{~b}}$ shear zones, whatever their scale, fits with this progressive deformation model. $\mathrm{D}_{1 \mathrm{a}}$ Keraf suturing is constrained between ca. 700-640 Ma (various age compilations; Stern, 1994; Abdelsalam and Stern, 1996b) and subsequent sinistral transpression is dated at ca. 640-580 Ma (lower age limit from Ar/Ar dating on hornblende and biotite in deformed granitoids (e.g., Abdelsalam et al., 1995, 1998; Abdelsalam and Stern, 1996a, 1996b). We can therefore consider that the syn- to late convergence $\mathrm{D}_{1 \mathrm{a}}-\mathrm{D}_{1 \mathrm{~b}}$ deformation and formation of the KS-KSZ occurred between $c a$. 700$580 \mathrm{Ma}($ Table 1$)$.

Later, brittle $\mathrm{D}_{2}$ deformation is characterized by discrete, top-to-the-east normal faults in meta-volcanosediments, especially formed along rheological contacts within weakened $\mathrm{C}_{1 \mathrm{~b}}$ shear zones. These normal faults have previously been observed in the Gabgaba gold district and interpreted as post-KSZ by Gaboury et al. (2020). However, very few orientation measurements have been made and these structures are very local in meta-volcanosediments. The regional significance of the extensional $\mathrm{D}_{2}$ deformation episode therefore remains in abeyance. We can only consider that $\mathrm{D}_{2}$ deformation occurred $<580 \mathrm{Ma}$ (Table 1). It is however worth noticing that significant north-striking normal faults have been characterized in the northeasternmost Saharan meta-craton, south to the Atmur-Delgo suture, a few hundred km away from the studied area. These extensional structures were attributed to a post-orogenic gravitational collapse that occurred at 550 Ma (Denkler et al., 1994; Harms et al., 1994; Abdelsalam et al., 2003).

Basically, the tectonic history unraveled within the central KS can be simplified into a single protracted deformation episode with a progressive change from thrusting to sinistral shearing, which is similar to the deformation episodes defined by Gaboury et al. (2020). Correspondence with deformation episodes of reference of the studied area, defined by remote sensing (Abdelsalam et al., 1995) and field work (Abdelsalam et al., 1998; Ahmed Suliman, 2000), is addressed in Table 1. The main $\mathrm{S}_{1 a}$ penetrative fabric and sinistral $\mathrm{C}_{1 \mathrm{~b}}$ strike-slip shear zones are well identified in both cases. However, most 
of the complex structural interferences defined in literature, such as fold interference patterns associated with multiple regional- to outcrop-scale fold stages (Fig. 1c; Abdelsalam et al., 1995 , 1998; Ahmed Suliman, 2000), have not been characterized during this study. The regional-scale significance of these structures is therefore questionable.

\subsubsection{Defining the central Keraf suture extent and deformation style}

The Keraf suture is a poorly studied area with uncertain shape and boundaries (Gaboury et al., 2020 and references therein). For instance, Gaboury et al. (2020), in agreement with Abdelsalam et al. (1998), suggested that the central KS is relatively narrow. They consider that the western limit of the KS, i.e., the contact between the Saharan meta-craton related Bayuda terrane to the west and the KPTA and Gabgaba terrane to the east (Fig. 1), is the several km-wide north-northwest-striking "West Corridor" hosting the Central Zone and UTM gold deposits (Figs. 2a, 3). If that was true, lithological units and deformation should be drastically different east and west of the "West Corridor", expressing the transition from the Bayuda terrane westwards and the ANS eastwards. Yet, we observe the same lithological units and structures $\left(\mathrm{S}_{1 \mathrm{a}}\right.$ and $\mathrm{C}_{1 \mathrm{~b}}$ ) east and west of the "West Corridor" (Figs. 2a, 3). Therefore, we would rather consider that the central KS is wider than suggested by Abdelsalam et al. (1998) and Gaboury et al. (2020), in line with the KS extent delimited by Ahmed Suliman (2000) (Figs. 1c, 2a, 3). The exact emplacement of the central KS western boundary could not be confirmed by field observations due to the presence of a Phanerozoic sedimentary cover overlying the Precambrian rocks of interest west of the limit from Ahmed Suliman (2000). The western extent of the central KS may thus remain underestimated.

Previously, the description of KSZ-related, second-order strike-slip structures was limited to the southern KS, where left-lateral displacement, if not estimated, is suggested to be more significant than for KSZ-related structures northwards (e.g., Abu Dis and 
Abu Hamed shear zones; Abdelsalam et al., 1998). However, although the structural framework of the central KS is dominated by Keraf suturing ( $\mathrm{D}_{1 \mathrm{a}}$ deformation), $\mathrm{C}_{1 \mathrm{~b}}$ shear zones are frequent within the central KS (Figs. 2a, 3). A $\mathrm{C}_{1 \mathrm{~b}}$ shear zone notably overprints the interpreted Bayuda terrane-KPTA limit (Figs. 2a, 3). It contradicts Ahmed Suliman (2000) who suggested that this boundary was a $\mathrm{D}_{1 \mathrm{a}}$-related thrust within the central KS (Fig. 1c). The central KS is therefore a complex area where the deformation style shifts between the thrusting- and strike-slip shearing-dominated northern and southern KS, respectively (Table 1; Abdelsalam and Stern, 1996b).

\subsection{Polyphase gold dominated by syn-Keraf shear zone mineralization in the Gabgaba gold district}

From field, macroscopic and microscopic observations, we suggest the existence of several gold events forming the Gabgaba gold district with distinct timing regarding the formation of the KS-KSZ (Fig. 15): (i) a first minor, pre-tectonic, (ii) a second major, late tectonic and (iii) a third potential, post-tectonic.

The first gold event we unraveled is low grade, i.e., $<1 \mathrm{~g} / \mathrm{t} \mathrm{Au}$, and limited to the WG03 deposit. Disseminated pyrrhotite and the presence of feldspar-rich segregationlike features within meta-diorite characterize mineralization. Despite the magmatic or magmatic-hydrothermal nature of this ore event remains hypothetical at this point, we suggest it occurred with the pre- $\mathrm{D}_{1 \mathrm{a}}$ diorite intrusion (Fig. 15). We therefore suggest the existence of a first gold generation coeval with magmatic accretion, probably during oceanic subduction and Keraf arc-back-arc basin development, prior to 750 Ma (Ries et al., 1985; Abdelsalam et al., 1998). Gaboury et al. (2020) did not distinguish this gold event at the WG03 deposit. Its contribution to the overall gold endowment is anyway thought to be very limited, regarding associated grades, dimensions and density of these mineralized features. 
The major gold event forming most of the WG03 deposit and the entire Central Zone deposit broadly relates to en échelon ore veining as a response to the late collisional ductile-brittle $\mathrm{D}_{1 \mathrm{~b}}$ shearing stage leading to the formation of the KSZ. The WG03 and Central Zone ore veins are associated with free gold mineralization and gold grades up to $30 \mathrm{~g} / \mathrm{t}$ Au. Gaboury et al. (2020) observed the same major ore-bearing structures at Central Zone and WG03, with similar metamorphic, carbon-rich aqueous fluid signature for both deposits. They also attributed the mineralization event to the KSZ-related late oblique convergence, at the retrograde amphibolite-greenschist facies transition. The main difference is that Gaboury et al. (2020) attributed ore veining at Central Zone to reverse faulting at the contacts between granitoids and surrounding meta-sediments, rather than strike-slip shearing. These two options are however not mutually exclusive as (i) they both fit with a roughly northwest-orientated compressional regime and (ii) the non-coaxial component of $\mathrm{D}_{1 \mathrm{~b}}$ deformation is thought to be very limited as discussed above. Besides, alteration is expressed by distal sericitization-(pyritization), proximal pyritization-carbonation and quartz-ankerite-albite-gold veining hosted in granitoids. The Central Zone deposit can therefore be considered as the perfect example for intrusion-hosted orogenic gold formed in a syn- to late compressional regime along second-order shear zones with typical structural, fluid, alteration and metamorphic footprints.

We attributed the formation of the UTM gold deposit to ore veining during late, brittle $\mathrm{D}_{2}$ extension and normal faulting along reactivated shear zones. However, (i) the $\mathrm{D}_{2}$ deformation is hardly interpretable as spatially limited to the UTM area, (ii) the genetic link between ore veins and normal faults is not clearly established and (iii) the UTM deposit displays numerous similarities with the Central Zone deposit. All these reasons make the interpretation of the UTM gold event highly uncertain. Vertical veins where not characterized by Gaboury et al. (2020) who only defined the gently eastdipping vein off-shoots into the regional $\mathrm{S}_{1 \mathrm{a}}$ fabric. They proposed that these veins formed 
along reverse faults activated during the KSZ formation, within the second-order "West Corridor" hosting both the Central Zone and UTM deposits. Their interpretation is supported by a fluid signature in gold-bearing veins at UTM similar to the one reported at Central Zone and WG03. Besides, this option has the merit to simplify the gold history of the Gabgaba gold district, considering a single, syn- $\mathrm{D}_{1 \mathrm{~b}}$ orogenic-like gold event accounting for most of the gold endowment in the central KS. The debate is still open.

Most of the gold mineralization in the central KS is therefore coeval with the late tectonic formation of the KSZ overprinting the KS. At Nubian shield-scale, 600 My-old gold mineralization hosted by quartz veins and related to ductile-brittle transcurrent structures is mostly characterized as orogenic gold (e.g., Elsamani et al., 2001; Klemm et al., 2001; Botros, 2002, 2004; Helmy et al., 2004; El Kazzaz, 2012; Osman, 2014; Helmy and Zoheir, 2015; Khalil et al., 2016; Fawzy, 2017; Zoheir et al., 2019a, 2019b, 2019c). However, there is also some evidence for gold mineralization during the magmatic accretion stage and early amalgamation of the ANS (ca. 830-640 Ma; age compilation by Abdelsalam and Stern, 1996b), such as the first gold event portrayed at the WG03 deposit or the syn-Atmur-Delgo suturing Galat Sufar South gold deposit (Perret et al., 2020). In the latter study, the authors indeed demonstrated that the regional AtmurDelgo deformation shapes the local structural setting and controls the formation and geometry of ore-shoots from the deposit to the macroscopic scales. Even if less documented, the existence of pre- to early-suturing gold events across the ANS should therefore not be underestimated. To go further and better constraint the gold mineral system expressed along the central KS, it appears now critical to (i) track the regional lithospheric evolution, (ii) put geochronological constraints on the deformation and gold events and (iii) study their gold input or remobilization nature and the potential genetic links between these gold episodes. 


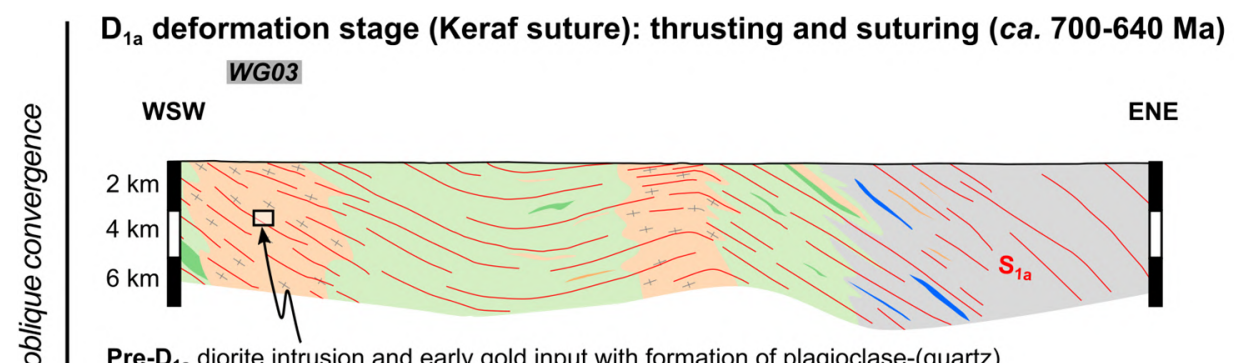

Pre- $\mathbf{D}_{1 \mathrm{a}}$ diorite intrusion and early gold input with formation of plagioclase-(quartz) segregation features and pyrrhotite-bound (?) invisible gold mineralization

Mostly $<1$ g/t Au grade

$D_{1 \mathrm{~b}}$ deformation stage (Keraf shear zone): strike-slip shearing (ca. 640-580 Ma) WG03

Central Zone

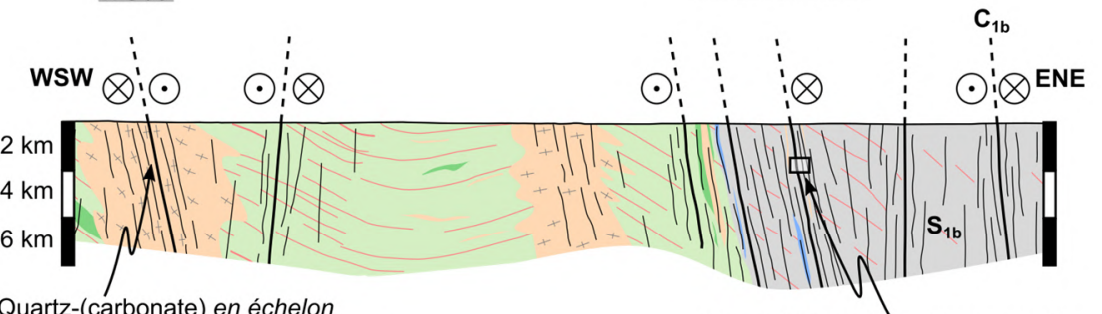

Granitoid intrusions deformed along

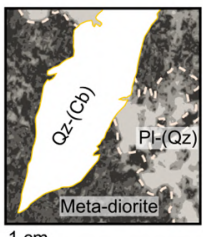

veining and free gold mineralization

$\mathrm{C}_{1 \mathrm{~b}}$ shear zones

Up to $30 \mathrm{~g} / \mathrm{t}$ Au grade

Granitoid-hosted quartz-carbonate-albite dilational veining and free gold mineralization

Up to $30 \mathrm{~g} / \mathrm{t}$ Au grade

$D_{2}$ deformation phase: local, brittle extension ( $\left.<580 \mathrm{Ma}\right)$

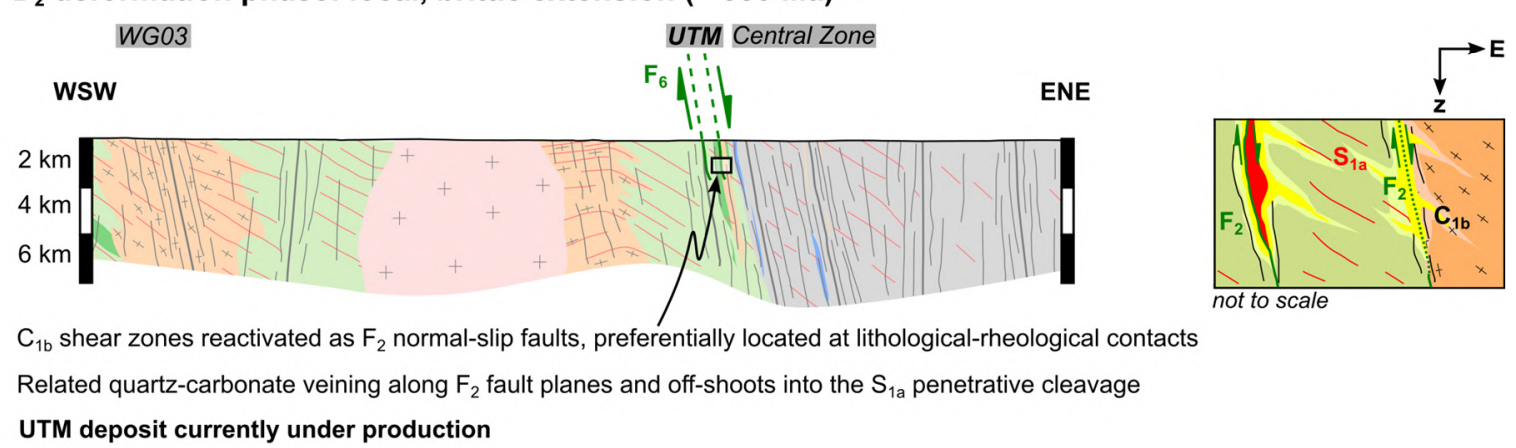

Figure 15: Relative timing of the Gabgaba district gold deposits (WG03, Central Zone and UTM) regarding the deformation history recorded by the central Keraf suture. Litho-structural legend is the same as in Figure 3 and mineral abbreviations are $\mathrm{Cb}=$ carbonate; $\mathrm{Pl}=$ plagioclase; $\mathrm{Qz}=$ quartz. See text for chronological constraint explanation and related references. Insets on the right correspond to schematic zooms of the black rectangle for each cross-section. 


\section{Conclusions}

Field observations suggest that the structural framework of the central Keraf suture is dominated by a progressive, ductile to ductile-brittle $\mathrm{D}_{1 \mathrm{a}}-\mathrm{D}_{1 \mathrm{~b}}$ deformation characterized by the regional $\mathrm{S}_{1 a}$ penetrative fabric and $\mathrm{C}_{1 \mathrm{~b}}$ sinistral shear zones. This deformation relates to Keraf suturing and subsequent left-lateral shearing in a prolonged northwestorientated compressional regime between $c a$. 700-580 Ma. However, the $\mathrm{D}_{1 \mathrm{a}}-\mathrm{D}_{1 \mathrm{~b}}$ deformation is thought to be coaxial-dominated shear and the non-coaxial deformation component, i.e., vertical and lateral displacement along structure planes, is weak. $\mathrm{A}_{1 \mathrm{~b}}$ shear zone overprints the boundary between the central Keraf suture and the Saharan meta-craton westwards which was not documented by previous studies. The central Keraf suture can therefore be seen as a transition zone between the northern Keraf suture, dominated by $\mathrm{D}_{1 \mathrm{a}}$ deformation, and the southern Keraf suture where $\mathrm{C}_{1 \mathrm{~b}}$ shear zones are more frequent. A late, brittle $\mathrm{D}_{2}$ normal faulting event reactivated inherited $\mathrm{C}_{1 \mathrm{~b}}$ shear zones. However, the significance of this deformation episode at regional scale remains uncertain as it is very local.

Relying on field and drill core relationships between structures and mineralization, we clearly define a polyphase gold history with two mineralizing events occurring in the $\sim 30 \mathrm{~km}$-wide Gabgaba gold district. The first one is pre- $\mathrm{D}_{1 \mathrm{a}}$ and related to magmatic accretion in the WG03 area but its contribution to the overall gold endowment is likely limited. The major gold event formed the WG03 and Central Zone deposits and is characterized by ore veining during late tectonic ductile-brittle Keraf strike-slip shearing. This mineralizing event can relate to orogenic gold, which is widespread at ANS-scale. The occurrence of a post-tectonic brittle gold event coeval with the $\mathrm{D}_{2}$ deformation episode is suggested at the UTM deposit, but its existence remains highly uncertain. 


\section{Acknowledgements}

The authors are grateful to the Manub and Managem team and especially to Attaiaa Hachem, Hassan Ait Benmouh, Mohamed Niyazi and El Alami Boukkari for their welcome on Gabgaba mining camp and their substantial logistical support. This work is part of Julien Perret's PhD project which benefited of a CIFRE funding, reference CIFRE N²017/1737, attributed by the French National Research and Technology Agency (ANRT). This manuscript was firstly submitted for publication to Ore Geology Reviews and benefited from the insightful review comments of Daniel Müller and two anonymous reviewers. Then, careful and discerning reviews by Taija Torvela and an anonymous reviewer on the second version of the manuscript greatly helped to reconsider our interpretations and suggest more realistic conclusions. Damien Delvaux is thanked for editorial handling. 


\section{References}

Abdelrahman, E., Matheis, G., Schandelmeier, H., Karfis, M.A., Gadir, I.A., El Khedir, M., 2017. Evolution of the Keraf back-arc basin: Constraints on the Nubian Shield margin. Geoscientific Research in Northeast Africa. CRC Press, 93-98.

Abdelrahman, E.M.A., 1993. Geochemical and geotectonic controls of the metallogenic evolution of selected ophiolite complexes from the Sudan. Reimer.

Abdelsalam, M.G., Abdel-Rahman, E.-S.M., El-Faki, E.-F.M., Al-Hur, B., El-Bashier, F.-R.M., Stern, R.J., Thurmond, A.K., 2003. Neoproterozoic deformation in the northeastern part of the Saharan Metacraton, northern Sudan. Precambrian Research 123, 203-221. https://doi.org/10.1016/S03019268(03)00068-8

Abdelsalam, M.G., Dawoud, A.S., 1991. The Kabus ophiolitic melange, Sudan, and its bearing on the western boundary of the Nubian Shield. Journal of the Geological Society 148, 83-92. https://doi.org/10.1144/gsjgs.148.1.0083

Abdelsalam, M.G., Stern, R.J., 1996a. Mapping Precambrian structures in the Sahara Desert with SIRC/X-SAR radar: The Neoproterozoic Keraf Suture, NE Sudan. Journal of Geophysical Research: Planets 101, 23063-23076. https://doi.org/10.1029/96JE01391

Abdelsalam, M.G., Stern, R.J., 1996b. Sutures and shear zones in the Arabian-Nubian Shield. Journal of African Earth Sciences 23, 289-310. https://doi.org/10.1016/S0899-5362(97)00003-1

Abdelsalam, M.G., Stern, R.J., Copeland, P., Elfaki, E.M., Elhur, B., Ibrahim, F.M., 1998. The Neoproterozoic Keraf Suture in Ne Sudan: Sinistral Transpression Along the Eastern Margin of West Gondwana. The Journal of Geology 106, 133-148. https://doi.org/10.1086/516012

Abdelsalam, M.G., Stern, R.J., Schandelmeier, H., Sultan, M., 1995. Deformational History of the Neoproterozoic Keraf Zone in NE Sudan, Revealed by Shuttle Imaging Radar. The Journal of Geology 103, 475-491. https://doi.org/10.1086/629771

Ahmed Suliman, E.T.B., 2000. KERAF SHEAR ZONE, NE SUDAN: GEODYNAMIC CHARACTERISTICS OF THE NILE CRATON-NUBIAN SHIELD BOUNDARY. PhD Thesis. Technical University of Berlin.

Almond, D.C., Ahmed, F., 1987. Ductile shear zones in the northern Red Sea Hills, Sudan and their implication for crustal collision. Geological Journal 22, 175-184. https://doi.org/10.1002/gj.3350220614

Augustin, J., Gaboury, D., Crevier, M., 2017. Structural and gold mineralizing evolution of the world-class orogenic Mana district, Burkina Faso: Multiple mineralizing events over 150 million years. Ore Geology Reviews 91, 981-1012. https://doi.org/10.1016/j.oregeorev.2017.08.007

Bailo, T., Schandelmeier, H., Franz, G., Sun, C.-H., Stern, R.J., 2003. Plutonic and metamorphic rocks from the Keraf Suture (NE Sudan): a glimpse of Neoproterozoic tectonic evolution on the NE margin of W. Gondwana. Precambrian Research 123, 67-80. https://doi.org/10.1016/S0301-9268(03)00044-5

Bedeaux, P., Pilote, P., Daigneault, R., Rafini, S., 2017. Synthesis of the structural evolution and associated gold mineralization of the Cadillac Fault, Abitibi, Canada. Ore Geology Reviews 82, 49-69. https://doi.org/10.1016/j.oregeorev.2016.11.029

Bennett, J.D., Mosley, P.N., 1987. Tiered-tectonics and evolution, Eastern Desert and Sinai, Egypt. Colloquium on African Geology. 14. 79-82.

Berhe, S.M., 1990. Ophiolites in Northeast and East Africa: implications for Proterozoic crustal growth. Journal of the Geological Society 147, 41-57.

Bierlein, F.P., Groves, D.I., Goldfarb, R.J., Dubé, B., 2006. Lithospheric controls on the formation of provinces hosting giant orogenic gold deposits. Mineralium Deposita 40, 874-886. https://doi.org/10.1007/s00126-005-0046-2

Blewett, R.S., Czarnota, K., Henson, P.A., 2010. Structural-event framework for the eastern Yilgarn Craton, Western Australia, and its implications for orogenic gold. Precambrian Research 183, 203-229. https://doi.org/10.1016/j.precamres.2010.04.004 
Bons, P.D., Elburg, M.A., Gomez-Rivas, E., 2012. A review of the formation of tectonic veins and their microstructures. Journal of Structural Geology 43, 33-62. https://doi.org/10.1016/j.jsg.2012.07.005

Botros, N.S., 2004. A new classifiaction of the gold deposits of Egypt. Ore Geology Reviews 25, 1-37.

Botros, N.S., 2002. Metallogeny of gold in relation to the evolution of the Nubian Shield in Egypt. Ore Geology Reviews 19, 137-164.

Burke, K., Sengör, C., 1986. Tectonic escape in the evolution of the continental crust. In: Barazangi, M., Brown, L. (Eds.), Geodynamics Series. American Geophysical Union, Washington, D. C., 41-53. https://doi.org/10.1029/GD014p0041

Chetty, T., 2017. Orogens. Proterozoic Orogens of India. Elsevier, 1-34. https://doi.org/10.1016/B978-012-804441-4.00001-8

Combes, V., Eglinger, A., André-Mayer, A.-S., Teitler, Y., Heuret, A., Gibert, P., Béziat, D., 2021. Polyphase gold mineralisation at the Yaou deposit, French Guiana. In: Torvela, T., Chapman, R.J., Lambert-Smith, J. (Eds.), Geological Society, London, Special Publications.

Cook, N.J., Chryssoulis, S.L., 1990. Concentrations of invisible gold in the common sulfides. The Canadian Mineralogist 28, 1-16.

Daigneault, R., Mueller, W.U., Chown, E.H., 2002. Oblique Archean subduction: accretion and exhumation of an oceanic arc during dextral transpression, Southern Volcanic Zone, Abitibi Subprovince Canada. Precambrian Research 115, 261-290.

Dawoud, A.S., 1980. Structural and metamorphic evolution of the area southwest of Abu Hamed, Nile Province, Sudan. Unpublished Ph. D Thesis, University of Khartoum.

Deditius, A.P., Reich, M., Kesler, S.E., Utsunomiya, S., Chryssoulis, S.L., Walshe, J., Ewing, R.C., 2014. The coupled geochemistry of $\mathrm{Au}$ and As in pyrite from hydrothermal ore deposits. Geochimica et Cosmochimica Acta 140, 644-670. https://doi.org/10.1016/j.gca.2014.05.045

Denkler, T., Franz, G., Schandelmeier, H., 1994. Tectonometamorphic evolution of the Neoproterozoic Delgo suture zone, northern Sudan. Geologische Rundschau 83, 578-590.

Denkler, T., Franz, G., Schandelmeier, H., Darbyshire, D.P.F., Harms, U., Pilot, J., 1993. Evolution of the south-western part of the Atmur-Delgo suture. Geoscientific Research in Northeast Africa. Balkema, Rotterdam Brookfield 87-89.

Domeier, M., Torsvik, T.H., 2014. Plate tectonics in the late Paleozoic. Geoscience Frontiers 5, 303-350.

Eglinger, A., André-Mayer, A.-S., Combes, V., Teitler, Y., Heuret, A., 2020. Les gisements d'or de la Guyane française. Géologues 206, 36-40.

Eglinger, A., Thébaud, N., Zeh, A., Davis, J., Miller, J., Parra-Avila, L.A., Loucks, R., McCuaig, C., Belousova, E., 2017. New insights into the crustal growth of the Paleoproterozoic margin of the Archean Kéména-Man domain, West African craton (Guinea): Implications for gold mineral system. Precambrian Research 292, 258-289. https://doi.org/10.1016/j.precamres.2016.11.012

Egyptian Geological Survey and Mining Authority, 1981. Geologic Map of Egypt., scale 1/2000000, Ministry of Industry and Mineral Resources - Egyptian Geological Survey and Mining Authority.

El Kazzaz, Y.A., 2012. Shear zones-related gold-bearing quartz veins in Shinai area, South eastern desert, Egypt. Egyptian Journal of Geology 56, 67-89.

Elsamani, Y., Almuslem, A.A., Tokhi, M.E., 2001. Geology and Geotectonic Classification of Pan-African Gold Mineralizations in the Red Sea Hills, Sudan. International Geology Review 43, 1117-1128. https://doi.org/10.1080/00206810109465064

Evuk, D., Franz, G., Frei, D., Lucassen, F., 2014. The Neoproterozoic evolution of the central-eastern Bayuda Desert (Sudan). Precambrian Research 240, 108-125. https://doi.org/10.1016/j.precamres.2013.10.015

Fawzy, K.M., 2017. Ore Mineralogical and Geochemical Studies on El-Daghbag-I Gold Deposit, Central Eastern Desert, Egypt. Open Journal of Geology 07, 395-419. https://doi.org/10.4236/ojg.2017.73027 
Feybesse, J.-L., Billa, M., Guerrot, C., Duguey, E., Lescuyer, J.-L., Milesi, J.-P., Bouchot, V., 2006. The paleoproterozoic Ghanaian province: Geodynamic model and ore controls, including regional stress modeling. Precambrian Research 149, 149-196.

Fontaine, A., Dubé, B., Malo, M., Turcotte, J., Doucet, D., 2018. Geology of the Cheechoo gold property, Eeyou Istchee Baie-James, Superior Province, northern Quebec. No. 8403. https://doi.org/10.4095/308244

Fontaine, A., Eglinger, A., Ada, K., André-Mayer, A.-S., Reisberg, L., Siebenaller, L., Le Mignot, E., Ganne, J., Poujol, M., 2017. Geology of the world-class Kiaka polyphase gold deposit, West African Craton, Burkina Faso. Journal of African Earth Sciences 126, 96-122. https://doi.org/10.1016/j.jafrearsci.2016.11.017

Fossen, H., Cavalcante, G.C.G., Pinheiro, R.V.L., Archanjo, C.J., 2019. Deformation - Progressive or multiphase? Journal of Structural Geology 125, 82-99. https://doi.org/10.1016/j.jsg.2018.05.006

Frisch, W., Pohl, W., 1986. Petrochemistry of some mafic and ultramafic rocks from the Mozambique Belt, SE Kenya. Mitteilungen Der Osterreichischen Geologischen Gesellschaft 78, 97-114.

Fritz, H., Abdelsalam, M., Ali, K.A., Bingen, B., Collins, A.S., Fowler, A.R., Ghebreab, W., Hauzenberger, C.A., Johnson, P.R., Kusky, T.M., Macey, P., Muhongo, S., Stern, R.J., Viola, G., 2013. Orogen styles in the East African Orogen: A review of the Neoproterozoic to Cambrian tectonic evolution. Journal of African Earth Sciences 86, 65-106. https://doi.org/10.1016/j.jafrearsci.2013.06.004

Gaboury, D., Nabil, H., Ennaciri, A., Maacha, L., 2020. Structural setting and fluid composition of gold mineralization along the central segment of the Keraf suture, Neoproterozoic Nubian Shield, Sudan: implications for the source of gold. International Geology Review 1-27. https://doi.org/10.1080/00206814.2020.1838336

Geological Research Authority of the Sudan, 1988. Geological Map of the Sudan., scale 1/1000000, Robertson Research.

Goldfarb, R.J., André-Mayer, A.-S., Jowitt, S.M., Mudd, G.M., 2017. West Africa: The World's Premier Paleoproterozoic Gold Province. Economic Geology 112, 123-143. https://doi.org/10.2113/econgeo.112.1.123

Goldfarb, R.J., Baker, T., Dubé, B., Groves, D.I., Hart, C.J.R., Gosselin, P., 2005. Distribution, character and genesis of gold deposits in metamorphic terranes. Economic Geology 100th Anniversary Volume, $407-450$.

Goldfarb, R.J., Groves, D.I., Gardoll, S., 2001. Orogenic gold and geologic time: a global synthesis. Ore Geology Reviews 18, 1-75.

Gray, D.R., Foster, D.A., Meert, J.G., Goscombe, B.D., Armstrong, R., Trouw, R.A.J., Passchier, C.W., 2008. A Damara orogen perspective on the assembly of southwestern Gondwana. Geological Society, London, Special Publications 294, 257-278.

Greiling, R.O., Abdeen, M.M., Dardir, A.A., El Akhal, H., El Ramly, M.F., Kamal, G.E.D., Osman, A.F., Rashwan, A.A., Rice, A.H.N., Sadek, M.F., 1994. A structural synthesis of the Proterozoic ArabianNubian Shield in Egypt. Geologische Rundschau 83, 484-501.

Greiling, R.O., Kroner, A., El-Ramly, M.F., Rashwan, A.A., 1988. Structural relationships between in the Southern and Central parts of the Eastern Desert of Egypt: details of a fold and thrust belt. The PanAfrican Belt of Northeast Africa and Adjacent Areas: Tectonic Evolution and Economic Aspects of a Late Proterozoic Oregon. 121-145.

Grenholm, M., 2019. The global tectonic context of the ca. 2.27-1.96 Ga Birimian Orogen - Insights from comparative studies, with implications for supercontinent cycles. Earth-Science Reviews 193, 260-298. https://doi.org/10.1016/j.earscirev.2019.04.017

Groves, D.I., Goldfarb, R.J., Robert, F., Hart, C.J., 2003. Gold deposits in metamorphic belts: overview of current understanding, outstanding problems, future research, and exploration significance. Economic Geology 98, 1-29. 
Groves, D.I., Santosh, M., Deng, J., Wang, Q., Yang, L., Zhang, L., 2019. A holistic model for the origin of orogenic gold deposits and its implications for exploration. Mineralium Deposita. https://doi.org/10.1007/s00126-019-00877-5

Groves, D.I., Santosh, M., Goldfarb, R.J., Zhang, L., 2018. Structural geometry of orogenic gold deposits: Implications for exploration of world-class and giant deposits. Geoscience Frontiers. https://doi.org/10.1016/j.gsf.2018.01.006

Harms, U., Darbyshire, D.P.F., Denkler, T., Hengst, M., Schandelmeier, H., 1994. Evolution of the Neoproterozoic Delgo suture zone and crustal growth in northern Sudan: geochemical and radiogenic isotope constraints. Geologische Rundschau 83, 591-603.

Helmy, H., Zoheir, B., 2015. Metal and fluid sources in a potential world-class gold deposit: El-Sid mine, Egypt. International Journal of Earth Sciences 104, 645-661. https://doi.org/10.1007/s00531-014-10946

Helmy, HassanM., Kaindl, R., Fritz, H., Loizenbauer, J., 2004. The Sukari GoldCo Mine, Eastern Desert, Egypt: structural setting, mineralogy and fluid inclusion study. Mineralium Deposita 39. https://doi.org/10.1007/s00126-004-0426-z

Hough, R.M., Noble, R.R.P., Reich, M., 2011. Natural gold nanoparticles. Ore Geology Reviews 42, 5561. https://doi.org/10.1016/j.oregeorev.2011.07.003

Johnson, P.R., Andresen, A., Collins, A.S., Fowler, A.R., Fritz, H., Ghebreab, W., Kusky, T., Stern, R.J., 2011. Late Cryogenian-Ediacaran history of the Arabian-Nubian Shield: A review of depositional, plutonic, structural, and tectonic events in the closing stages of the northern East African Orogen. Journal of African Earth Sciences 61, 167-232. https://doi.org/10.1016/j.jafrearsci.2011.07.003

Johnson, P.R., Zoheir, B.A., Ghebreab, W., Stern, R.J., Barrie, C.T., Hammer, R.D., 2017. Gold-bearing volcanogenic massive sulfides and orogenic-gold deposits in the Nubian Shield. South African Journal of Geology 120, 63-76.

Kerrich, R., Wyman, D., 1990. Geodynamic setting of mesothermal gold deposits: An association with accretionary tectonic regimes. Geology 18, 882. https://doi.org/10.1130/00917613(1990)018<0882:GSOMGD>2.3.CO;2

Khalil, K.I., Moghazi, A.M., El Makky, A.M., 2016. Nature and Geodynamic Setting of Late Neoproterozoic Vein-Type Gold Mineralization in the Eastern Desert of Egypt: Mineralogical and Geochemical Constraints. In: Bouabdellah, M., Slack, J.F. (Eds.), Mineral Deposits of North Africa. Springer International Publishing, Cham, 353-370. https://doi.org/10.1007/978-3-319-31733-5_14

Klemm, D., Klemm, R., Murr, A., 2001. Gold of the Pharaohs - 6000 years of gold mining in Egypt and Nubia. Journal of African Earth Sciences 33, 643-659. https://doi.org/10.1016/S0899-5362(01)00094$\mathrm{X}$

Kröner, A., 1993. The Pan African belt of northeastern and eastern Africa, Madagascar, southern India, Sri Lanka and East Antarctica: Terrane amalgamation during formation of the Gondwana supercontinent. In: Thorweihe, U., Schandelmeier, H. (Eds.), Geoscientific Research in Northeast Africa. CRC Press, 3-9.

Kusky, T.M., Abdelsalam, M., Tucker, R.D., Stern, R.J., 2003. Evolution of the East African and related orogens, and the assembly of Gondwana. Precambrian Research 123, 81-85. https://doi.org/10.1016/S0301-9268(03)00062-7

Le Mignot, E., Reisberg, L., André-Mayer, A.-S., Bourassa, Y., Fontaine, A., Miller, J., 2017. Re-Os Geochronological Evidence for Multiple Paleoproterozoic Gold Events at the Scale of the West African Craton. Economic Geology 112, 145-168. https://doi.org/10.2113/econgeo.112.1.145

Li, Z.X., Bogdanova, S.V., Collins, A.S., Davidson, A., De Waele, B., Ernst, R.E., Fitzsimons, I.C.W., Fuck, R.A., Gladkochub, D.P., Jacobs, J., Karlstrom, K.E., Lu, S., Natapov, L.M., Pease, V., Pisarevsky, S.A., Thrane, K., Vernikovsky, V., 2008. Assembly, configuration, and break-up history of Rodinia: A synthesis. Precambrian Research 179-210. https://doi.org/10.1016/j.precamres.2007.04.021 
Managem, 2014. Exploration activities in Sudan.

Managem, 2011. Exploration activities in Sudan.

Masurel, Q., Eglinger, A., Thébaud, N., Allibone, A., André-Mayer, A.-S., McFarlane, H., Miller, J., Jessell, M., Aillères, L., Vanderhaeghe, O., Salvi, S., Baratoux, L., Perrouty, S., Begg, G., Fougerouse, D., Hayman, P., Wane, O., Tshibubudze, A., Parra-Avila, L., Kouamélan, A., Amponsah, P.O., 2021. Paleoproterozoic gold events in the southern West African Craton: review and synopsis. Mineralium Deposita. https://doi.org/10.1007/s00126-021-01052-5

Meinhold, K.D., 1979. The Precambrian basement complex of the Bayuda Desert, northern Sudan.

Merdith, A.S., Collins, A.S., Williams, S.E., Pisarevsky, S., Foden, J.D., Archibald, D.B., Blades, M.L., Alessio, B.L., Armistead, S., Plavsa, D., Clark, C., Müller, R.D., 2017. A full-plate global reconstruction of the Neoproterozoic. Gondwana Research 50, 84-134. https://doi.org/10.1016/j.gr.2017.04.001

Mole, D.R., Kirkland, C.L., Fiorentini, M.L., Barnes, S.J., Cassidy, K.F., Isaac, C., Belousova, E.A., Hartnady, M., Thebaud, N., 2019. Time-space evolution of an Archean craton: A Hf-isotope window into continent formation. Earth-Science Reviews 196, 102831. https://doi.org/10.1016/j.earscirev.2019.04.003

Mosley, P.N., 1993. Geological evolution of the late Proterozoic "Mozambique Belt" of Kenya. Tectonophysics 221, 223-250.

Mueller, A.G., 2017. Structural setting of Fimiston- and Oroya-style pyrite-telluride-gold lodes, Paringa South mine, Golden Mile, Kalgoorlie: 1. Shear zone systems, porphyry dykes and deposit-scale alteration zones. Mineralium Deposita. https://doi.org/10.1007/s00126-017-0747-3

Mueller, A.G., Hagemann, S.G., McNaughton, N.J., 2016. Neoarchean orogenic, magmatic and hydrothermal events in the Kalgoorlie-Kambalda area, Western Australia: constraints on gold mineralization in the Boulder Lefroy-Golden Mile fault system. Mineralium Deposita. https://doi.org/10.1007/s00126-016-0665-9

Osman, A.E.M., 2014. An integrated metallotect and petrographic model for gold mineralization in the Eastern Desert of Egypt; a new prospecting vision. Journal of Egyptian Pure and Applied Sciences 52, $41-54$.

Passchier, C.W., Trouw, R.A.J., 2005. Microtectonics, 2nd edition. ed. Springer, Berlin, New-York.

Perret, J., Eglinger, A., André-Mayer, A.-S., Aillères, L., Feneyrol, J., Hartshorne, C., Abanyin, E., Bosc, R., 2020. Subvertical, linear and progressive deformation related to gold mineralization at the Galat Sufar South deposit, Nubian Shield, NE Sudan. Journal of Structural Geology 135. https://doi.org/10.1016/j.jsg.2020.104032

Pokrovski, G.S., Kokh, M.A., Proux, O., Hazemann, J.-L., Bazarkina, E.F., Testemale, D., Escoda, C., Boiron, M.-C., Blanchard, M., Aigouy, T., Gouy, S., de Parseval, P., Thibaut, M., 2019. The nature and partitioning of invisible gold in the pyrite-fluid system. Ore Geology Reviews 109, 545-563. https://doi.org/10.1016/j.oregeorev.2019.04.024

Rabeau, O., Royer, J.-J., Jébrak, M., Cheilletz, A., 2013. Log-uniform distribution of gold deposits along major Archean fault zones. Mineralium Deposita 48, 817-824. https://doi.org/10.1007/s00126-0130470-7

Reich, M., Kesler, S.E., Utsunomiya, S., Palenik, C.S., Chryssoulis, S.L., Ewing, R.C., 2005. Solubility of gold in arsenian pyrite. Geochimica et Cosmochimica Acta 69, 2781-2796. https://doi.org/10.1016/j.gca.2005.01.011

Ries, A.C., Shackleton, R.M., Dawoud, A.S., 1985. Geochronology, geochemistry and tectonics of the NE Bayuda Desert, N Sudan: Implications for the western margin of the late Proterozoic fold belt of NE Africa. Precambrian Research 30, 43-62. https://doi.org/10.1016/0301-9268(85)90028-2

Ries, A.C., Shackleton, R.M., Graham, R.H., Fitches, W.R., 1983. Pan-African structures, ophiolites and mélange in the Eastem Desert of Egypt: a traverse at 26 N. Journal of the Geological Society 140, 7595. 
Ries, A.C., Vearncombe, J.R., Price, R.C., Shackleton, R.M., 1992. Geochronology and geochemistry of the rocks associated with a late Proterozoic ophiolite in West Pokot, NW Kenya. Journal of African Earth Sciences (and the Middle East) 14, 25-35.

Rutter, E.H., 1986. On the nomenclature of mode of failure transitions in rocks. Tectonophysics 122, 381387. https://doi.org/10.1016/0040-1951(86)90153-8

Sawkins, F.J., 1990. Metal Deposits in Relation to Plate Tectonics. Springer Berlin, Berlin.

Schandelmeier, H., Wipfler, E., Küster, D., Sultan, M., Becker, R., Stern, R.J., Abdelsalam, M.G., 1994. Atmur-Delgo suture: A Neoproterozoic oceanic basin extending into the interior of northeast Africa. Geology 22, 563. https://doi.org/10.1130/0091-7613(1994)022<0563:ADSANO>2.3.CO;2

Seton, M., Müller, R.D., Zahirovic, S., Gaina, C., Torsvik, T., Shephard, G., Talsma, A., Gurnis, M., Turner, M., Maus, S., 2012. Global continental and ocean basin reconstructions since 200 Ma. EarthScience Reviews 113, 212-270.

Shackleton, R.M., 1986. Precambrian collision tectonics in Africa. Geological Society, London, Special Publications 19, 329-349.

Shackleton, R.M., Ries, A.C., 1984. The relation between regionally consistent stretching lineations and plate motions. Journal of Structural Geology 6, 111-117.

Shackleton, R.M., Ries, A.C., Graham, R.H., Fitches, W.R., 1980. Late Precambrian ophiolitic melange in the Eastern Desert of Egypt. Nature 285, 472-474.

Simard, M., Gaboury, D., Daigneault, R., Mercier-Langevin, P., 2013. Multistage gold mineralization at the Lapa mine, Abitibi Subprovince: insights into auriferous hydrothermal and metasomatic processes in the Cadillac-Larder Lake Fault Zone. Mineralium Deposita 48, 883-905. https://doi.org/10.1007/s00126-013-0466-3

Snoke, A.W., Tullis, J., Todd, V.R., 1998. The Princeton Atlas of Fault-related Rocks. Princeton University Press.

Stern, R.J., 1994. Arc Assembly and Continental Collision in the Neoproterozoic East African Orogen: Implications for the Consolidation of Gondwanaland. Annual Review of Earth and Planetary Sciences 22, 319-351. https://doi.org/10.1146/annurev.ea.22.050194.001535

Stern, R.J., Abdelsalam, M.G., Schandelmeier, H., Sultan, M., Wickham, S., 1993. Carbonates of the Keraf Zone, NE Sudan; a Neoproterozoic (ca. 750Ma) passive margin on the eastern flank of West Gondwanaland. Geological Society of America Annual Meeting, Abstracts with Programs. A49.

Stern, R.J., Kröner, A., Bender, R., Reischmann, T., Dawoud, A.S., 1994. Precambrian basement around Wadi Haifa, Sudan: a new perspective on the evolution of the East Saharan Craton. Geologische Rundschau 83, 564-577.

Sturchio, N., Sultan, M., Sylvester, P., Batiza, R., Hedge, C., 1984. Geology, age, and origin of the Meatiq Dome: implications for the Precambrian stratigraphy and tectonic evolution of the Eastern Desert of Egypt.

Tadesse, S., Milesi, J.-P., Deschamps, Y., 2000. Geology and Mineral Map of Ethiopia., scale 1/2000000.

Thébaud, N., Allibone, A., Masurel, Q., Eglinger, A., Davis, J., André-Mayer, A.-S., Miller, J., Ouedrago, M.F., Jessell, M., 2020. Chapter XX The Paleoproterozoic (Rhyacian) Gold Deposits of West Africa. Society of Economic Geologist, Special Publication 18.

Tikoff, B., Blenkinsop, T., Kruckenberg, S.C., Morgan, S., Newman, J., Wojtal, S., 2013. A perspective on the emergence of modern structural geology: Celebrating the feedbacks between historical-based and process-based approaches. The Web of Geological Sciences: Advances, Impacts, and Interactions. Geological Society of America. https://doi.org/10.1130/2013.2500(03)

Turlin, F., Jébrak, M., De Souza, S., Turcotte, J., 2019. Topological characterization of a polyphased goldbearing vein network. Journal of Structural Geology 128, 103872. https://doi.org/10.1016/j.jsg.2019.103872

Twiss, R.J., Moores, E.M., 2007. Structural Geology. (c) WH Freeman and Company. New York 532. 
Vail, J.R., 1985. Pan-African (late Precambrian) tectonic terrains and the reconstruction of the ArabianNubian Shield. Geology 13, 839. https://doi.org/10.1130/0091-7613(1985)13<839:PLPTTA >2.0.CO;2 Vail, J.R., 1983. Pan-African crustal accretion in north-east Africa. Journal of African Earth Sciences (1983) 1, 285-294. https://doi.org/10.1016/S0731-7247(83)80013-5

Vail, J.R., 1979. Outline of geology and mineralization of the Nubian Shield east of the Nile valley, Sudan In: Tahon, S> A>,(ed.). Evolution and mineralization of the Arabian Nu bian Shield, 1, 97-107. Pergamon press.

Vearncombe, J.R., 1983. A dismembered ophiolite from the Mozambique belt, west Pokot, Kenya. Journal of African Earth Sciences (1983) 1, 133-143.

Weinberg, R.F., Hodkiewicz, P.F., Groves, D.I., 2004. What controls gold distribution in Archean terranes? Geology 32, 545. https://doi.org/10.1130/G20475.1

Weinberg, R.F., Van der Borgh, P., Bateman, R.J., Groves, D.I., 2005. Kinematic history of the BoulderLefroy shear zone system and controls on associated gold mineralization, Yilgarn Craton, Western Australia. Economic Geology 100, 1407-1426.

Zoheir, B., Emam, A., Soliman, N., Holzheid, A., 2019a. Gold Metallogeny of the Egyptian South Eastern Desert. Springer Berlin Heidelberg, Berlin, Heidelberg, 261-263. https://doi.org/10.1007/978-3-03001575-6_63

Zoheir, B., Steele-MacInnis, M., Garbe-Schönberg, D., 2019b. Orogenic gold formation in an evolving, decompressing hydrothermal system: Genesis of the Samut gold deposit, Eastern Desert, Egypt. Ore Geology Reviews 105, 236-257. https://doi.org/10.1016/j.oregeorev.2018.12.030 